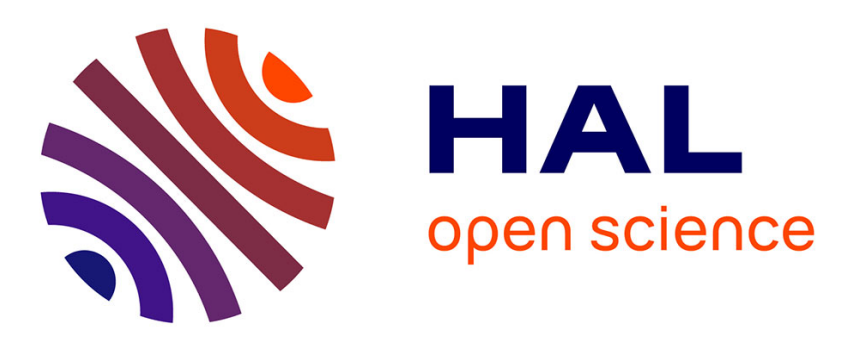

\title{
A decision analysis approach for optimal groundwater monitoring system design under uncertainty
}

\author{
N. B. Yenigül, A. M. M. Elfeki, C. van den Akker, F. M. Dekking
}

\section{To cite this version:}

N. B. Yenigül, A. M. M. Elfeki, C. van den Akker, F. M. Dekking. A decision analysis approach for optimal groundwater monitoring system design under uncertainty. Hydrology and Earth System Sciences Discussions, 2006, 3 (1), pp.27-68. hal-00298639

\section{HAL Id: hal-00298639 \\ https://hal.science/hal-00298639}

Submitted on 3 Jan 2006

HAL is a multi-disciplinary open access archive for the deposit and dissemination of scientific research documents, whether they are published or not. The documents may come from teaching and research institutions in France or abroad, or from public or private research centers.
L'archive ouverte pluridisciplinaire HAL, est destinée au dépôt et à la diffusion de documents scientifiques de niveau recherche, publiés ou non, émanant des établissements d'enseignement et de recherche français ou étrangers, des laboratoires publics ou privés. 
Hydrol. Earth Syst. Sci. Discuss., 3, 27-68, 2006

www.copernicus.org/EGU/hess/hessd/3/27/

SRef-ID: 1812-2116/hessd/2006-3-27

European Geosciences Union

Papers published in Hydrology and Earth System Sciences Discussions are under open-access review for the journal Hydrology and Earth System Sciences

\section{A decision analysis approach for optimal groundwater monitoring system design under uncertainty}

Abstract

Conclusions

Introduction

References

Figures

${ }^{1}$ Delft University of Technology, Faculty of Civil Engineering and Geosciences, Water Resources Section, The Netherlands

${ }^{2}$ King Abdulaziz University, Faculty of Meteorology, Environment and Arid Land Agriculture, Department of Hydrology and Water Resources Management, Saudi Arabia

${ }^{3}$ Delft University of Technology, Faculty of Electrical Engineering, Mathematics and Computer Science, The Netherlands

on leave from: Irrigation and Hydraulics Dept., Faculty of Engineering, Mansoura University, Mansoura, Egypt

Received: 8 November 2005 - Accepted: 14 November 2005 - Published: 3 January 2006

Correspondence to: N. B. Yenigül (n.b.yenigul@citg.tudelft.nl)

(C) 2006 Author(s). This work is licensed under a Creative Commons License.
Title Page

Tables

14

$\triangleleft$

Back

groundwater design

N. B. Yenigül et al.

\section{Full Screen / Esc}

Print Version

Interactive Discussion 


\section{Abstract}

Groundwater contamination is the degradation of the natural quality of groundwater as a result of human activity. Landfills are one of the most common human activities threatening the groundwater quality. The objective of the monitoring systems is to de-

5 tect the contaminant plumes before reaching the regulatory compliance boundary in order to prevent the severe risk to both society and groundwater quality, and also to enable cost-effective counter measures in case of a failure. The detection monitoring problem typically has a multi-objective nature. A multi-objective decision model (called MONIDAM) which links a classic decision analysis approach with a stochastic simula10 tion model is applied to determine the optimal groundwater monitoring system given uncertainties due to the hydrogeological conditions and contaminant source characteristics. A Monte Carlo approach is used to incorporate uncertainties. Hydraulic conductivity and the leak location are the random inputs of the simulation model. The design objectives considered in the model are: (1) maximizing the detection probability, (2)

15 minimizing the contaminated area and, (3) minimize the total cost of the monitoring system. The results show that the monitoring systems located close to the source are optimal except for the cases with very high unit installation and sampling cost and/or very cheap unit remediation cost.

\section{Introduction}

20 The growing awareness of environmental issues more often reflects a reactionary response of public throughout the last years. For instance, the fear of groundwater contamination from a leaky landfill has been a major reason for the difficulty in locating landfills, due to such public reactions to the local governments. When faced with sceptical, and even reactionary public, the ability of technical experts to present designs that minimize risk becomes very important. In case of a landfill, concern often centres on the risk of exposure to contaminated groundwater. This can be reduced in sev-

\section{HESSD}

3, 27-68, 2006

MONIDAM for optimal groundwater monitoring system design

N. B. Yenigül et al.

Title Page

Abstract Introduction

Conclusions

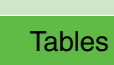

References

Tables

Figures

14

$\rightarrow$

$\triangleleft$

Back

Close

Full Screen / Esc

Print Version

Interactive Discussion 
eral ways, such as the locating the facility in a hydrogeologic environment that inhibits the transport of contaminants into potential groundwater resources, and design of the landfill in a way to minimize chance of leakage. However, despite all counter measures the contamination risk cannot be completely eliminated. The adverse impacts of 5 landfill leachates on adjacent groundwater have prompted a great number of studies (e.g., Kjeldsen et al., 1995; Chen and Wang, 1997; Riediker et al., 2000; Koliopolous, 2003; Yousef, 2005). Regulatory agencies require groundwater monitoring programs at solid waste landfills, hazardous waste sites, and other sites, where potential release of chemicals to the subsurface is a concern, so that the risk of exposure can be further o reduced by monitoring the quality of the groundwater.

The object of detection monitoring is to detect the plume early enough that appropriate action can be taken to prevent exposure. According to USEPA (1986) detection monitoring wells (at least three downgradient wells) should be placed at locations where they will intersect all possible pathways of contamination. The document also 15 suggests placing the wells as close as possible to the source so that the contaminants are detected as soon as a release occurs. However early detection of contaminants implies that small contaminant plumes must be detected, which can be difficult with a limited number of wells such as proposed by the regulations (namely at least three downgradient monitoring wells). The likelihood of detection increases when a large number of monitoring wells are located, however, the monitoring and construction cost also increases. Hence a tradeoff exists between the likelihood of detecting contaminant plumes, the plume size, and the associated cost of construction, operation and maintenance of the monitoring system. Consequently, the design of a groundwater detection monitoring system can be formulated with three conflicting objectives: (1)

25 Maximize the probability of detection of contaminant plumes, (2) minimize the contaminated area, and (3) minimize the total cost of the monitoring system (i.e., construction, maintenance, and remediation cost, if necessary). Therefore the design of an efficient monitoring system is quite complicated and becomes even more difficult when uncertainty, which is characteristic of groundwater problems, is incorporated in the problem.
HESSD

$3,27-68,2006$

\section{MONIDAM for optimal groundwater monitoring system design}

N. B. Yenigül et al.

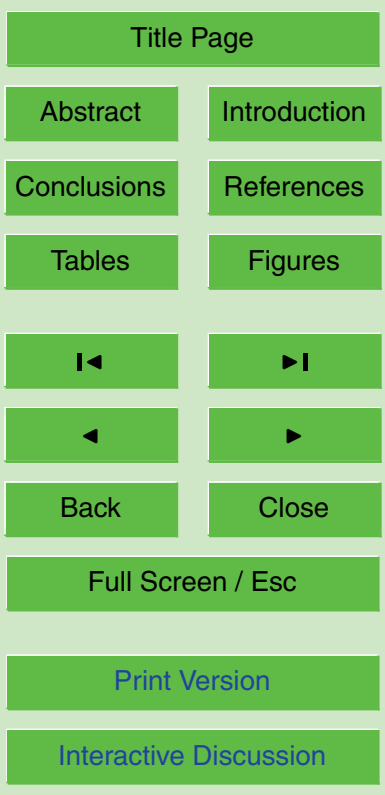

EGU 
Several studies are cited in the literature addressing the different aspects of the detection monitoring problem. Rouhani and Hall (1988) used a variance based method to investigate the effect of a sampling program in groundwater quality monitoring network design, considering neither flow nor transport models but only geostatistical tools. Hu5 dak (2001) devised a graphical approach to configure detection wells at the downgradient of a landfill. He evaluated detection capabilities of graphically designed monitoring networks in aquifers dominated by intergranular porosity in his later work (Hudak, 2002), with no regard to the uncertainties due to the subsurface heterogeneity and contaminant leak location. Hudak and Loaiciga (1993), Meyer et al. (1994), Storck et 10 al. (1997), Mahar and Datta (1997) and Montas et al. (2000) are some examples in which detection monitoring problem has been approached from an optimization perspective.

Optimization involves the determination of optimal values for a set of decision variables in an engineering system and optimality is defined with respect to a specified objective function and is subject to a set of constraints (Freeze et al., 1990). An optimal solution for a multi-objective problem, such as a detection monitoring design, cannot be determined based solely on objective function values. Moreover solution of a multiobjective groundwater detection monitoring problem within a stochastic framework to include uncertainties due to the hydrogeological characteristics may be computationally very expensive and less feasible in practice for most common engineering projects.

Massmann and Freeze (1987a, b), Massmann et al. (1991), Freeze et al. (1992) and Jardine et al. (1996) used a decision analysis approach to deal with the problem of groundwater detection monitoring system design. Decision analysis provides a rational step by step approach to aid in the decision making process and most often compares alternatives on a common basis: money and preference is based on a specified objective function, including the risks, costs, and benefits of alternatives. Since the process of engineering design is often described as a sequence of decisions between alternatives under conditions of uncertainty and hydrogeologists and engineers are often asked to address alternatives in the most traditional engineering practice, decision

\section{HESSD}

$3,27-68,2006$

\section{MONIDAM for optimal groundwater monitoring system design}

N. B. Yenigül et al.

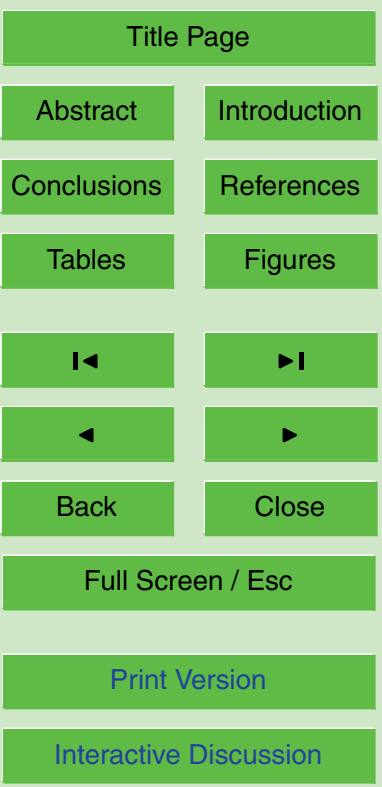

EGU 
analysis is well-suited to the risk-based philosophy of engineering design (Gorelick et al., 1993). Moreover, when one incorporates the uncertainties, lower computational effort is required to solve the multi-objective decision problem. Therefore in this study detection monitoring design is approached from a decision analysis perspective. The 5 simulation model used by Yenigul et al. (2005) for reliability assessment of monitoring systems at landfill sites is linked with a classic decision analysis approach to formulate a decision analysis model called MONIDAM. It incorporates the three conflicting objectives presented previously in a systematic way, as well as the uncertainties due to subsurface heterogeneity and leak location to determine the optimal groundwater 10 monitoring system.

\section{Model description}

Monte Carlo simulation, an economical analysis of the objective function for monitoring systems, and the selection of the optimal monitoring system are the principal steps of the decision model MONIDAM. It allows for the comparison of monitoring systems 15 alternatives (Systems 1 through $n$ ). The following paragraphs provide an overview of each step of the decision analysis framework of MONIDAM illustrated in Fig. 1.

\subsection{Monte Carlo simulation}

A simulation-based model (adapted from Elfeki, 1996) coupled with a two dimensional finite difference flow model and a random walk particle-tracking model is used to determine the optimal monitoring system. Uncertainties in the hydrogeology and contaminant source are incorporated in the model using Monte Carlo simulations. Subsurface heterogeneity, as reflected by spatial variability of the hydraulic conductivity $K$ is assumed to be the major contributor to the hydrogeologic uncertainty and is modelled here as a log normally distributed, second order stationary stochastic process $Y=\ln K$ 25 (see e.g. Gelhar, 1986). The hydraulic conductivity stochastic process is here assumed

\section{MONIDAM for optimal groundwater monitoring system design}

N. B. Yenigül et al.

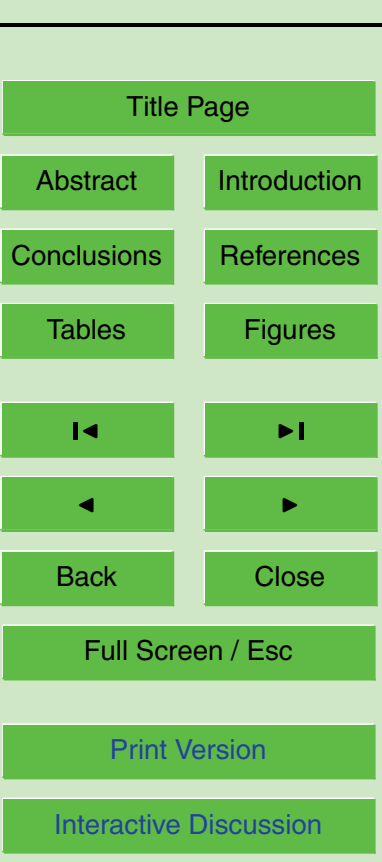


to be isotropic. The variance of $Y$ is denoted by $\sigma_{Y}^{2}$.

Uncertainty in the contaminant source is assumed to be limited to the source location and random leak locations along the downgradient edge of the landfill are drawn from a uniform probability distribution.

5 The ability of the monitoring systems to detect the contaminant plumes is represented by the system reliability model. If the concentration value at any well of monitoring system $j$ exceeds a given threshold concentration $C_{T H}$, the monitoring system detects the contaminant plume and the binary variable $I_{d(j)}$ equals 1 and zero otherwise. Once all the Monte Carlo simulation runs have completed $P_{d(j)}$, the detection 10 probability of system $j$, is estimated as the ratio of the number of simulation runs in which the contaminants are detected over the total number of simulation runs. Finally, the probability of failure $P_{f(j)}$ of a system to detect the plume is equal to $1-P_{d(j)}$. For further information related to the simulation model and the assumptions considered, the reader is referred to Yenigul et al. (2005).

Another output variable of each Monte Carlo simulation run is a variable representing the area of contamination associated with the size of the plume at the time of detection, or the area of contamination when the plume remains undetected at the end of the monitoring period. When a given system $j$ detects a plume, an associated contamination area is obtained. However, the area of contamination at detection varies 20 from one simulation run to another due to the variability in leak location and subsurface heterogeneity. Therefore, rather than producing a single contaminant plume every time a system detects a plume, a range of plume sizes at detection is obtained. Using the individual plume sizes at detection, cumulative distributions $F\left(A \mid d_{j}\right)$ of plume size $A$ can be determined for monitoring system $j$. Likewise, the cumulative distribution $F\left(A \mid f_{j}\right)$ of 25 plume size given no detection can be determined by using the individual plume sizes that remain undetected at the end of the monitoring period. These probability distributions are used in the economical analysis of the objective function.

\section{HESSD}

$3,27-68,2006$

\section{MONIDAM for optimal groundwater monitoring system design}

N. B. Yenigül et al.

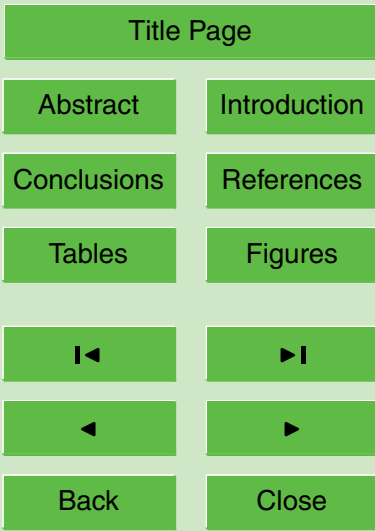

Full Screen / Esc

Print Version

Interactive Discussion 
The economic objective of design must be to meet the technical objective in such a way so as to maximize the profit (or minimize the loss) to the owner-operator (Freeze et al., 1990). From this perspective, an objective function defined as the net present value of

5 the expected stream of benefits, cost, and risks taken over an engineering time horizon and discounted at the market interest rate, (Gorelick et al., 1993):

$Z_{j}=\sum_{t=0}^{T}\left[\frac{1}{(1+i)^{t}}\right]\left[B_{j}(t)-C_{j}(t)-R_{j}(t)\right](j=1, \ldots \ldots, n)$

where $Z_{j}=$ objective function for alternative $j[\$]$,

$T=$ planning horizon [years],

$10 \quad i=$ annual discount rate [decimal fraction],

$B_{j}(t)=$ benefits of alternative $j$ in year $t[\$]$,

$C_{j}(t)=$ costs of alternative $j$ in year $t[\$]$, and

$R_{j}(t)=$ risks of alternative $j$ in year $t[\$]$.

MONIDAM for optimal groundwater monitoring system design

N. B. Yenigül et al.

15 The risks, $R_{j}(t)$, associated with alternative $j$ in year $t$ are defined as:

$R_{j}(t)=P_{f(j)}(t) C_{f(j)}(t) \gamma\left(C_{f(j)}\right)(j=1, \ldots, n)$

where $P_{f(j)}(t)=$ probability of failure of alternative $j$ in year $t$ [decimal fraction], $C_{f(j)}(t)=$ cost associated with a failure of alternative $j$ in year $t[\$]$ $\gamma()=$. normalized utility function [decimal fraction, $\geq 1$ ].

The utility function $\gamma($.$) in Eq. (2) allows one to take into account the possible$ risk-averse tendencies of some decision makers. A risk-adverse decision maker will set the utility function to larger than one. Small owner-operators who do not have large net worth are the most likely to use a risk-adverse utility function. Larger companies are more likely to take a risk-neutral approach (Gorelick et al., 1993).

Title Page

Abstract

Conclusions

Tables

References

Figures

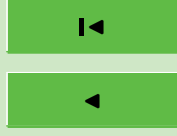

$>$ I

Back

Close

Full Screen / Esc

Print Version

Interactive Discussion 
In this study only the construction of a detection monitoring system within the property boundaries of the landfill is considered. There is no analysis of the trade-off between the facility design and monitoring. It is assumed that the revenues generated by the landfill would be the same regardless of the monitoring strategy adopted. Thus it 5 is possible to neglect the benefit terms. Since the trade-off between facility and monitoring is not considered, the capital costs of constructing and operating the landfill are also the same regardless of the monitoring strategy chosen. Hence, these costs are neglected and only those costs directly associated with the construction and operation of the detection monitoring system are taken into account. On the other hand the time 10 dependencies will not be important due to the three assumptions made in this study: (1) the leak in the landfill will occur at the beginning of the monitoring period, and the contaminant plume will be either detected at any time during the monitoring period, or failure will occur if it is not detected at the end of the monitoring period, (2) installation cost of the monitoring wells is the only cost occurs in year zero, the year before

the landfill and monitoring system begin operation, and (3) the annual unit costs for monitoring and remediation cost per unit volume of contamination are constant for the whole monitoring period. With all these assumptions, the objective function in Eq. (1) can be simply written as the summation of the time independent costs and risk:

$Z_{j}=-\left[C_{j}+R_{j}\right](j=1, \ldots, n)$

20 The minus sign can be removed from Eq. (3) without loss of generality. The construction and operation cost $C_{j}$ of monitoring system $j$ can be estimated as:

$C_{j}=C_{m w} n_{m w}$

where $C_{m w}=$ unit installation and sampling cost of a monitoring well( $\$ /$ per well), $n_{m w}=$ number of the wells in monitoring system $j$.

25

For a site with no monitoring system, the risk term is equal to the expected costs associated with failure. However, for the sites with a detection monitoring,
HESSD

$3,27-68,2006$

MONIDAM for optimal groundwater monitoring system design

N. B. Yenigül et al.

Title Page
Abstract

Conclusions

Tables

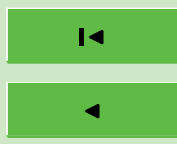

Back
Introduction

References

Figures

$\rightarrow$ I

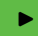

Close
Full Screen / Esc

Print Version

Interactive Discussion 
the risk term is expanded to allow for possibility of the plume being detected and remediated before failure occurs. Therefore, the risk term in this study represents the expected cost associated with both detection of the contaminant plume and failure if it HESSD remains undetected at the end of the monitoring period. From a risk-neutral approach 5 perspective the risk term $\left(R_{j}\right)$ associated with monitoring system $j$ can accordingly be defined as:

$R_{j}=P_{d(j)} C_{d r(j)}+P_{f(j)} C_{f r(j)}(j=1, \ldots, n)$

where $P_{d(j)}=$ the probability of detection of monitoring system $j$,

$C_{d r(j)}=$ remediation cost associated with detection of contaminant plume by monitoring 10 system $j[\$]$,

$P_{f(j)}=$ probability of failure of monitoring system $j$ and,

$C_{f r(j)}=$ remediation cost when monitoring system $j$ fails to detect the contaminant plume [\$].

15 The clean up cost associated with detection of contaminant plume by monitoring system $j$ can be obtained as:

$C_{d r(j)}=C_{r} V_{d(j)}$

where $C_{r}$ is the remediation cost per unit volume $\left[\$ / \mathrm{m}^{3}\right], V_{d}(j)$ is volume of contamination given detection by monitoring system $j\left[\mathrm{~m}^{3}\right]$. Similarly, the cost associated with

20 failure, $C_{f r(j)}$ is $C_{r}$ times volume of contamination given no detection by monitoring system $j, V_{f(j)}\left[\mathrm{m}^{3}\right]$.

As mentioned above in Sect. 2.1 the plume areas associated either with detection or no detection follow a probability distribution and the volume of contamination is defined by the expected plume area times the aquifer thickness, $B=B(A)[\mathrm{m}]$. Let $f\left(A \mid d_{j}\right)=F^{\prime}$ ${ }_{25}\left(A \mid d_{j}\right)$ be the probability density of the plume size. Then the risk term for monitoring

3, 27-68, 2006

MONIDAM for optimal groundwater monitoring system design

N. B. Yenigül et al.

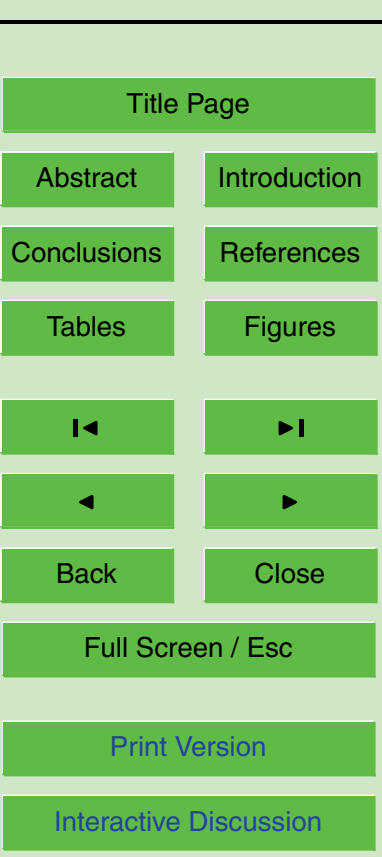


system $j$ can be found by:

$R_{j}=P_{d(j)} \int_{-\infty}^{+\infty} C_{r}(A) B(A) A f\left(A \mid d_{j}\right) d A+P_{f(j)} \int_{-\infty}^{+\infty} C_{r}(A) B(A) A f\left(A \mid f_{j}\right) d A$

$3,27-68,2006$

Since the unit cost of remediation and the aquifer thickness are assumed to be constant, Eq. (7) can be simplified to:

$5 \quad R_{j}=P_{d(j)} C_{r} B E\left(A_{d(j)}\right)+P_{f(j)} C_{r} B E\left(A_{f(j)}\right)$

where $E_{A\left(d_{j}\right)}$ is the expected contaminated area given detection by monitoring system $j$ and $E_{A\left(d_{j}\right)}$ contaminated area given no detection by monitoring system $j$. The final form of the objective function, which is a general form of MONIDAM represents the expected total cost for each monitoring system $j=1, \ldots n$ and it is:

$$
\underbrace{Z_{j}}_{\begin{array}{c}
\text { expected } \\
\text { total } \\
\text { cost }
\end{array}}=\underbrace{C_{j}}_{\begin{array}{c}
\text { construction } \\
\text { and operation } \\
\text { cost }
\end{array}}+P_{d(j)} \underbrace{C_{r} B E_{A\left(d_{j}\right)}}_{\begin{array}{l}
\text { expected cost } \\
\text { given detection, } \\
E\left(C \mid d_{j}\right)
\end{array}}+P_{f(j)} \underbrace{C_{r} B E_{A\left(f_{j}\right)}}_{\begin{array}{l}
\text { expected cost } \\
\text { given detection, } \\
E\left(C \mid f_{j}\right)
\end{array}}
$$

\subsection{Selection of the optimal monitoring system}

The "best" system is the system that uses the smallest number of wells to enable the largest detection probability while minimizing the cost of monitoring and remediation. Once Eq. (9) determines the expected total cost for each monitoring system, the alternative with the minimum expected total cost $\left(Z_{\min }\right)$ is the "optimal" groundwater detection monitoring system.

\section{MONIDAM for optimal groundwater monitoring system design}

N. B. Yenigül et al.

Title Page

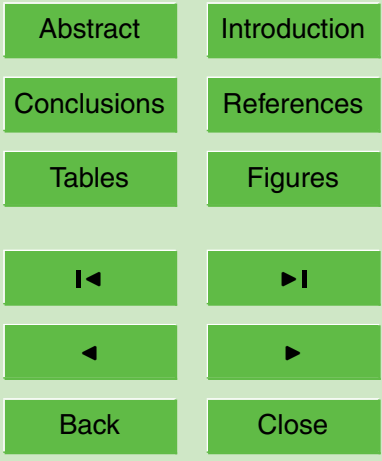

Full Screen / Esc

Print Version

Interactive Discussion 


\section{Example problem}

A series of numerical experiments was carried out to study the use of MONIDAM in optimal groundwater monitoring system design. The sensitivity of the objective function values of the model is illustrated by varying the model parameters.

5 3.1. Model domain and discretization

The numerical experiments are carried out using a model of a generic landfill facility and groundwater system. Dimensions of the model domain and the parameters that have been used are chosen to reflect conditions of typical solid waste landfills. The model domain is defined by $0 \leq x \leq 500 \mathrm{~m}$ and $0 \leq y \leq 400 \mathrm{~m}$ (Fig. 2). The model is discretized with grid cells of $2 \mathrm{~m}$ by $2 \mathrm{~m}$ in both $\mathrm{x}$ - and $y$-directions. In general, the higher the discretization level of flow and transport problems, the better will be the subsequent solution of flow and transport equations. However, the higher the discretization level, the greater the computational effort required. Therefore a balance must be found between the level of discretization and the computational expense. Ababou et al. (1989) 15 suggested as a rule of thumb the following ratio between the grid cell size $(\Delta x)$ and correlation length $(\lambda)$ :

$\frac{\lambda}{\Delta x} \geq 1+\sigma_{Y}^{2}$

Bellin et al. (1992) found that a ratio of $\lambda / \Delta x=4$ in the range of $\sigma_{Y}^{2} \leq 1.6$ provided satisfactory accuracy and convergence of computations. The principal ratio applied in this paper is $\lambda / \Delta x=7.5$ and it also satisfies the ratio suggested by Ababou et al. (1989). Therefore, this discretization level is considered to be sufficient for all cases tested and presented in the following.

A rectangular landfill is located at $100 \leq x \leq 150 \mathrm{~m}$ and $150 \leq y \leq 250 \mathrm{~m}$ in the model domain. The monitoring systems considered are composed of a line of wells parallel to the $y$-axis, covering the length of the landfill. It may be noted that a longer line of
HESSD

$3,27-68,2006$

MONIDAM for optimal groundwater monitoring system design

N. B. Yenigül et al.

Title Page

\section{Abstract}

Conclusions
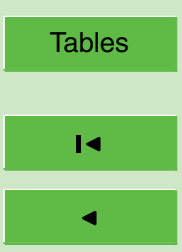

Back
Introduction References Figures
Full Screen / Esc

Print Version

Interactive Discussion 
wells that extends beyond the length of the landfill could also be considered. However, determination of the appropriate longer length would involve major assumptions on the dispersivity of the medium. This simple pattern adjusts to the shape of the landfill used and the groundwater flow characteristics in the example. For actual case studies with

5 a less ideal shape than in the example, monitoring wells placed along the downstream perimeter of the facility or along a curve parallel to it are the configurations equivalent to the row configurations presented here.

Monitoring systems composed of $3,4,5,6,8,10,12,16$, and 20 monitoring wells are evaluated to study the effect of number of wells on the reliability of single row monitoring 10 systems. Since the number of monitoring wells in the system must cover the length of the landfill, the spacing of wells in the single row monitoring systems decreases as the number of the number of monitoring wells increases. The spacing $\Delta s$ between the wells and the distance $d$ from the edge of the landfill are normalized with respect to the length of the landfill $L$ perpendicular to the flow, to get rid of the specific landfill size.

15 For instance, a monitoring system composed of 3 monitoring wells has normalized well spacing, $n w s(\Delta s / L)$ of 0.33 , which means that one third of the landfill is monitored by each monitoring well in the system. All these monitoring systems are located from $10 \mathrm{~m}$ to $190 \mathrm{~m}$ downgradient of the landfill with $10 \mathrm{~m}$ distance apart in order to determine the influence of the location of single row monitoring systems. The distances from the source are also normalized with respect to the length of the landfill for generalization purposes, as well as for consistency with nws. As the area of potential leak locations is assumed to be the downgradient edge of the landfill the location of the source of contaminant is at $x$ equal to $150 \mathrm{~m}$, the distance from the contaminant source, $d$ can be obtained as the difference between the $x$-coordinate of the single row monitoring 25 systems and location of the source of contamination (Fig. 2). Table 1 presents spacing, $\Delta s$, normalized well spacing, nws for different number of monitoring wells in monitoring systems with different $\mathrm{x}$-coordinates, distance from the contaminant source, $d$, and normalized distance from the source, ndfs .

HESSD

3, 27-68, 2006

MONIDAM for optimal groundwater monitoring system design

N. B. Yenigül et al.

\section{Title Page}

\section{Abstract}

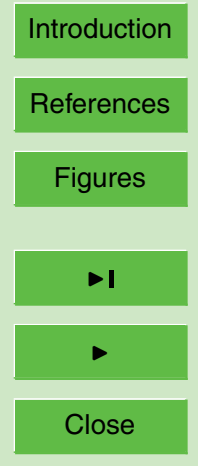

Back

Close

Full Screen / Esc

Print Version

Interactive Discussion 
The aquifer is assumed to be confined, with given hydraulic head at left and right boundaries, resulting in a macroscopically constant hydraulic gradient of 0.001 . The porosity of the medium equals 0.30 . Uncertainties due to contaminant source location

5 and subsurface heterogeneity are incorporated in the model using 1000 Monte Carlo simulations. In this study, subsurface heterogeneity is reflected by the spatial variability of the hydraulic conductivity. Hence hydraulic conductivity is treated as a random space function. The natural logarithm of the isotropic hydraulic conductivity $[Y=\ln (K)]$ is modelled as a stationary Gaussian field with a geometric mean value of $2.23 \mathrm{~m} /$ day, a 10 variance set at $\sigma_{Y}^{2}=0.4$ and the isotropic covariance of $Y$ is chosen to be of exponential form with correlation length, $\lambda=15 \mathrm{~m}$.

\subsection{Parameter values used in random walk particle tracking model}

For the transport model a condition of a zero dispersive flux is imposed on the top and bottom boundary, and the initial background concentration in the model domain is set 15 to zero. Since the flow direction is aligned with $x$-axis, the only source dimension that is treated as a random variable is the position along the $y$-axis. The area of potential leak locations is the downgradient edge of the landfill (Fig. 2). The contaminant leak is assumed to be a point source, as it would result in a plume which is most difficult to detect and the source location is drawn from a uniform probability distribution between

$20 \mathrm{y}$-coordinates of $150 \leq y \leq 250 \mathrm{~m}$ for each Monte Carlo run. Dispersion is incorporated in the model by introducing micro scale longitudinal $\left(\alpha_{L}\right)$ and transverse $\left(\alpha_{T}\right)$ dispersivities. The ratio between $\alpha_{L}$ and $\alpha_{T}$ is assumed to be $1 / 10$ (Bear, 1972) and $\alpha_{L}$ is set to $0.5 \mathrm{~m}$. The simulation procedure assumes that the source is continuous and provides a constant mass rate of $1 \mathrm{mg} / \mathrm{l} / \mathrm{day}$. The threshold concentration (detection limit) at which detection occurs is set at $0.5 \%$ of the initial source concentration. This level represents the EPA public health risk level for drinking water for the most common contaminant types released to groundwater mainly via leaks from landfills such as

\section{MONIDAM for optimal groundwater monitoring system design}

N. B. Yenigül et al.

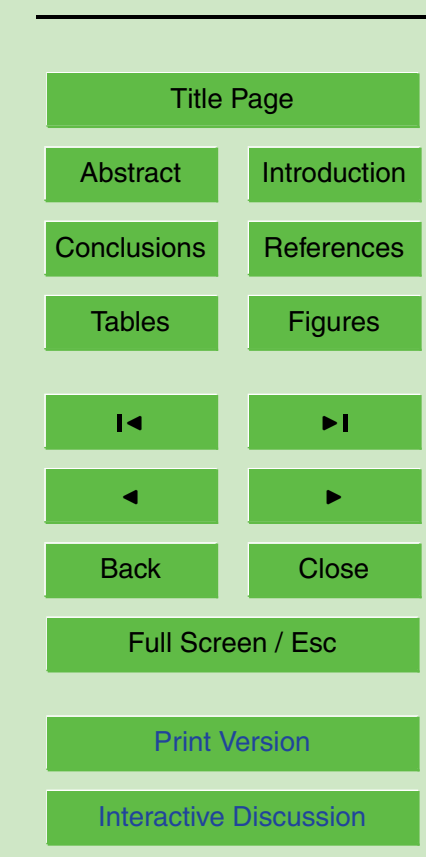

EGU 
benzene, carbon tetrachloride and 1,1,2-Tricloroethane. The number of the particles used throughout the example is 2000 . This was determined after sensitivity analyses showed that plumes did not go undetected due to an insufficient number of particles and $0.05 \mathrm{mg} / \mathrm{l}$ of a threshold value corresponds to 40 particles, which is a sufficient 5 number for determination of concentration in one grid cell (Kinzelbach, 1986). In this study monitoring wells are located in the centre of the grid cell and have a dimension of one grid cell. Contaminants are assumed to be conservative and to be completely mixed over the depth of the aquifer, which is presumed to be $50 \mathrm{~m}$ in the example problem. A monitoring period of 30 years is considered while monitoring is assumed to be carried out each quarter of a year.

\section{Discussion of results}

The decision model MONIDAM evaluated 171 potential monitoring system alternatives to determine the best monitoring system, which enables the highest detection probability while minimizing the cost of monitoring and remediation with use of the least results of the three principal steps of MONIDAM, namely Monte Carlo simulation, economical analysis of the objective function for monitoring systems, the selection of the optimal monitoring system, plus sensitivity to model parameters are discussed in the following subsections.

\subsection{Monte Carlo simulation results}

\subsubsection{Reliability evaluation}

The reliability of a groundwater monitoring system is measured by the probability of detection $P_{d}$. Figure 3 presents the reliability of monitoring systems at different distances from the contaminant source. Each data point represents one monitoring system eval-

\section{HESSD}

$3,27-68,2006$

\section{MONIDAM for optimal groundwater monitoring system design}

N. B. Yenigül et al.

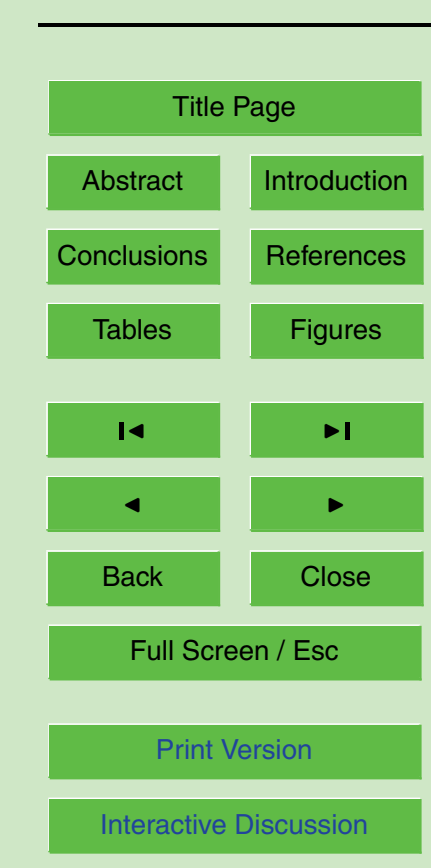

EGU 
uated. The reliability of monitoring systems increases with distance from the contaminant source. Since plumes begin with a small size and spread out as they migrate away from the source, detection of a plume is difficult at close distances and becomes easier as the plume expands with time and distance from the contaminant source. Hence 5 there is a greater chance of detecting plumes for the systems composed of few wells, when they are placed away from the source (i.e., nws $>0.25$ and $n d f s<0.5$ ). Moreover, for a given ndfs, the probability of detection increases when nws decreases. However the reliability of the monitoring system is $100 \%$ regardless of the $n d f s$ for the systems with nws less than 0.08 . Additional wells would not be cost effective for improving sys10 tem reliability in such cases. The analysis also showed that for a monitoring system with nws greater than 0.08 there is a ndfs at which $100 \%$ reliability is achieved. For instance for a monitoring system with nws equal to 0.10 this point occurs at $n d f s$ equal to 0.30 . However, for the site dimensions and distance from the source analyzed the common practice of 3 -well monitoring system does never reach $100 \%$ reliability.

15 4.1.2. Area of the contaminant plume

When a given monitoring system detects a contaminant plume, an associated contaminated area $A_{d}$ is obtained. When the monitoring system fails to detect the contaminant plume, the contaminated area $A_{f}$ at the end of the monitoring period (in this case 30 years) is estimated. However, the plume size, either detected or not, varies from one 20 realization to another due to the variability in the source location and hydrogeologic characteristics. Therefore rather than producing a single plume size a range of plume sizes is determined for each monitoring system. Using the individual plume areas associated either with detection or no detection cumulative distributions of contaminated areas are determined for each monitoring system. In other words, the area of the contaminant plume is treated as a random variable and modelled using a mean value $E\left(A_{d}\right)$ or $E\left(A_{f}\right)$ and standard deviation $\sigma\left(A_{d}\right)$ or $\sigma\left(A_{f}\right)$ determined from the Monte Carlo simulations. The expected area of the contaminant plume may generally indicate the extent of contamination The contaminated area values estimated during the ground-

HESSD

$3,27-68,2006$

MONIDAM for optimal groundwater monitoring system design

N. B. Yenigül et al.

\section{Title Page}

Abstract

Conclusions

Tables References

Figures

14

$\rightarrow$

4

Back

Close

Full Screen / Esc

Print Version

Interactive Discussion 
water transport simulation were normalized by dividing the actual areas (as measured in square meters) by $10000 \mathrm{~m}^{2}$ simply to render all (normalized) areas less than one. This is just a matter of convenience in presenting the plots.

Figure 4 shows a plot of the expected area of contamination given detection $E\left(A_{d}\right)$ 5 as a function of $n d f s$ for different $n w s$ values. For a given $n w s$ value, $E\left(A_{d}\right)$ increases significantly as the distance from the contaminant source increases. Hence, to minimize the contaminated area, the most effective system is the one located very close to contaminant source. On the other hand, $E\left(A_{d}\right)$ does not increase appreciably and stays more or less constant as the nws increase, since nws is not a parameter that has effect on spreading and consequently the size of the plume but ndfs is a parameter that has influence on the contaminated area in terms of the distance where the plume is detected. Given that $A_{f}$ is defined as the contaminated area estimated at the end of the monitoring period (in this case 30 years) neither ndfs nor nws has influence on the plume size that is not detected by the given monitoring system. Hence $E\left(A_{f}\right)$ re-

mains almost constant with respect to well spacing and distance from the contaminant source.

The distance between the monitoring systems and the contaminant source has influence on the variability of $E\left(A_{d}\right)$. Figure 5 shows the coefficient of variation of expected contaminated area given detection $C V_{A(d)}=E\left(A_{d}\right) / \sigma\left(A_{d}\right)$ as a function of ndfs for monitoring systems with different nws values. For the systems close to the contaminant source $C V_{A(d)}$ is very high mainly because $\sigma\left(A_{d}\right)$ is small at the start. As $n d f s$ increases, the variability in $A_{d}$ decreases since the detected plumes reaches stationarity as it moves further away from the source. The effect of leak location is not as significant relative to systems placed close to the contaminant source, since at far distances the plume size is so large that detection is basically unaffected by the initial leak location. This trend is the same for systems composed of any number of wells, with $C V_{A(d)}$ levelling off at large distances from the contaminant source.

\section{HESSD}

$3,27-68,2006$

MONIDAM for optimal groundwater monitoring system design

N. B. Yenigül et al.

Title Page

Abstract

Conclusions

Tables

Tables

14

$\triangleleft$

Back

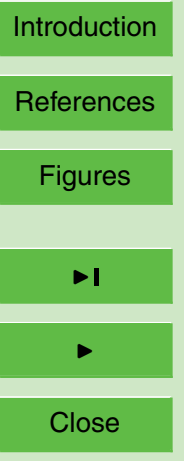

Full Screen / Esc

Print Version

Interactive Discussion 
The economic analysis of the monitoring system alternatives has been performed considering a unit installation and sampling cost of $\$ 20000$ per well and a unit remediation cost of $5 \$ / \mathrm{m}^{3}$ (unit cost estimates are based on James and Gorelick, 1994). Figure 6 5 presents cost values as a function of $n d f s$ for a single row system with a nws of 0.33 . The curves characterized by $P_{d} E(C \mid d)$ and $P_{f} E(C \mid f)$ represent the associated costs given detection by the monitoring system and cost associated with the failure of the monitoring system, respectively (cf. Eq. 9) The associated cost given detection by the monitoring system increases with distance due to the increase in $A_{d}$ as the plume moves away from the contaminant source. On the other hand cost associated with the failure of the monitoring system shows a decreasing trend, due to the fact that $A_{f}$ stays almost constant. The line characterized with $C$ represents the cost of construction and operation of monitoring system. Since only a 3 well monitoring system is considered in this plot, $C$ is constant. Ultimately, the curve symbolized by $Z$ represents the expected 5 total cost for the 3 well monitoring system as a function of $n d f s$ and is simply the sum of the three previous curves. It shows that there is a point where the cost is minimized. In other words, there is a tradeoff between the objectives as a function of ndfs.

\subsection{Selection of the optimal monitoring system}

Figure 7 presents the expected total cost, $Z$ as a function of ndfs for all single row 20 systems considered in this study. The trough shaped curves for systems with nws between 0.33 and 0.12 indicate a tradeoff between the contaminated area, detection probability, and cost of the monitoring system. Thus, for systems with $n w s=0.33$, it is better to locate wells further away from the contaminant source (ndfs=1.4) where a large enough detection probability exists and the contaminated area is somewhat limited .The optimal location, which maximizes the detection probability while minimizing the contaminated area, is at an intermediate distance for the monitoring systems with nws between 0.25 and 0.12 . As also seen from Fig. 8, the monitoring systems with

\section{MONIDAM for optimal groundwater monitoring system design}

N. B. Yenigül et al.

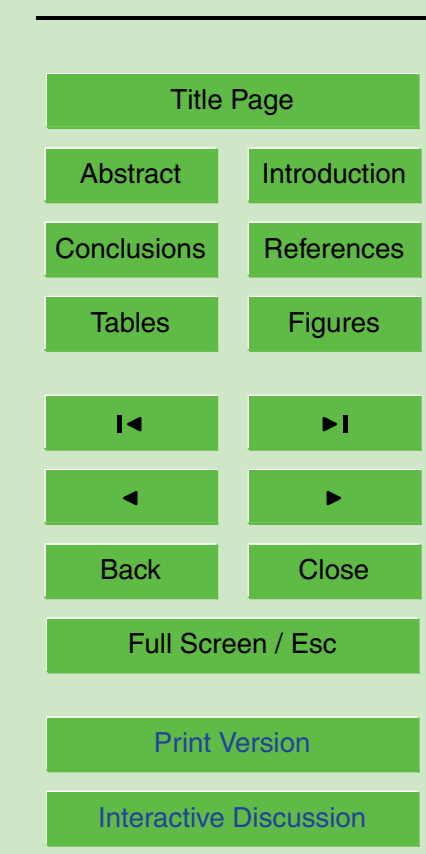

EGU 
nws less than 0.12 that are located very close to the contaminant source (ndfs $<0.3)$ lead to the lowest expected total cost. This is actually because a high detection probability is reached very close to the contaminant source with use of a multitude of wells for monitoring.

$5 \quad$ Figure 9 shows the minimum expected total cost, $Z_{\min }$ as a function of $n w s$. For large nws values, the minimum expected cost is large, but as the number of monitoring wells increases the expected minimum cost first reaches a minimum, and then increases. This shows that the additional monitoring wells are not cost effective when nws $<0.08$ since they do not contribute to increase the reliability (which is already 100\%), and do not reduce the expected area of contamination.

\subsection{Sensitivity to model parameters}

The objective function values and optimal locations determined by MONIDAM are functions of the parameters used in flow and random walk particle tracking model. The results of numerical experiments performed are particularly sensitive to those parameters that have greatest influence on the size and shape of the contaminant plumes. Dispersivity, subsurface heterogeneity, contaminant source size, threshold concentration, sampling frequency, unit installation and sampling cost unit cost and unit remediation cost are generally considered to be the most significant parameters. The influence of these parameters on the detection probability of monitoring systems was previously studied in Yenigul et al. (2005), but for the case of an instantaneous leak. Based on the results of the previous study and the characteristics of the example problem presented here, not only the sensitivity analysis for unit cost and sampling frequency are performed but also the influences of dispersivity and the subsurface heterogeneity on the results are discussed once more in the following sections.

\section{HESSD}

3, 27-68, 2006

\section{MONIDAM for optimal groundwater monitoring system design}

N. B. Yenigül et al.

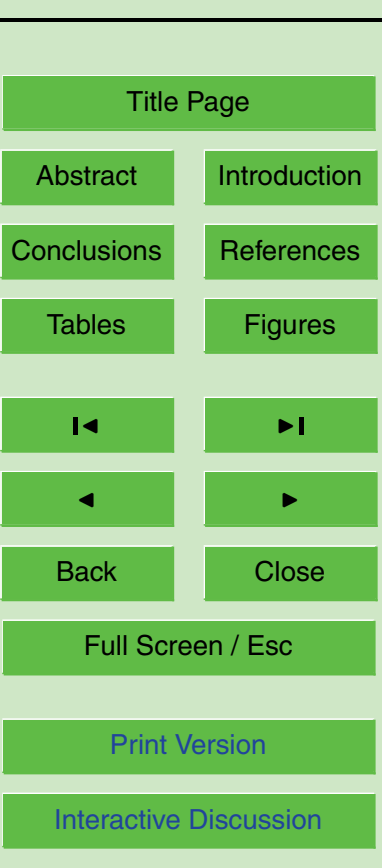


Dispersivity of the medium is the parameter controlling the spreading of the plume. The longitudinal dispersivity controls the elongation of the plume with time and distance from the contaminant source in the direction of flow, whereas transverse dispersivity

5 dominates the spreading of the plume (width of the plume) in the direction perpendicular to the flow direction. In order to examine the influence of dispersivity $\alpha_{L}$ is set to values between $0.1 \mathrm{~m}$ and $1.2 \mathrm{~m}$. As mentioned earlier, the ratio of $\alpha_{L}$ to $\alpha_{T}$ is taken constant at a value of 10 . For single row systems, the main consideration in terms of the well spacing is the plume width hence evaluation of $P_{d}$ and $E\left(A_{d}\right)$ as a function 10 of $\alpha_{T}$ is presented in Figs. 10 and 11, respectively. As the dispersivity of the medium increases the detection probability of a given monitoring system increases since dispersivity is the parameter that controls the spreading of the plume (see e.g., Meyer et al., 1994; Storck et al., 1997; Yenigul et al., 2005). The higher the dispersivity of the medium the wider the plume gets as it moves further away from the source. Therefore,

15 likewise $E\left(A_{d}\right)$ increases significantly as the dispersivity of medium increases since the plume becomes wider as it moves away from the source. The results are representative for other monitoring systems evaluated in this study. Furthermore the influence of threshold concentration (detection limit) and initial source size will be similar to the effect of dispersivity on both $P_{d}$ and $E\left(A_{d}\right)$ as both parameters are directly in relation with the width of the plume. The effective width of the plume increases when the threshold concentration (detection limit) is reduced. Likewise the larger the initial leak size is, the wider the plume will be. Consequently $P_{d}$ and $E\left(A_{d}\right)$ will increase in both cases (see Yenigul et al., 2005). Eventually the increased $P_{d}$ and $E\left(A_{d}\right)$ values will amplify the expected total cost for a given monitoring system.

\section{MONIDAM for optimal groundwater monitoring system design}

N. B. Yenigül et al.

\section{4.4.2. Sensitivity to subsurface heterogeneity}

Subsurface heterogeneity, represented here by the spatial variability of the hydraulic conductivity, is one of the important factors controlling the migration of contaminants in

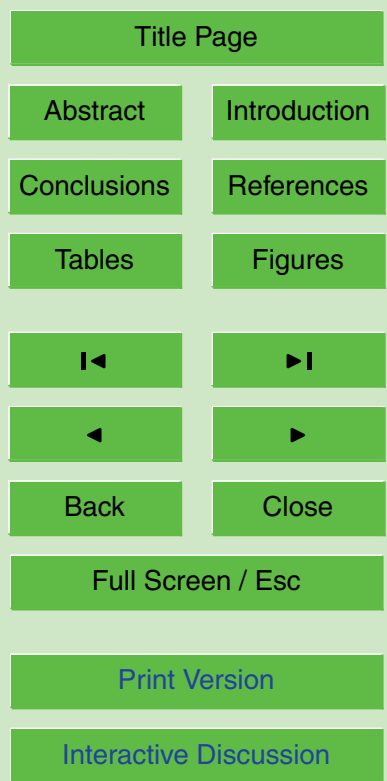


porous media. The variance $\sigma_{Y}^{2}$ of $Y$ is the parameter that characterizes the degree of heterogeneity of the subsurface. A high variance will produce a highly heterogeneous field with hydraulic conductivity values spanning a wide range, while a low variance will produce a more homogeneous-like field. To investigate the influence of heterogeneity $5 \sigma_{Y}^{2}$ is set to $0,0.4,0.6,1.0$ and 1.2. Figures 12 and 13 show $P_{d}$ and $E\left(A_{d}\right)$ as a function of $\sigma_{Y}^{2}$, respectively. $P_{d}$ of the monitoring system decreases as $\sigma_{Y}^{2}$ increases. This is due to the fact that the contaminant plumes are more likely to become irregularly shaped in heterogeneous media and may go undetected easier due to variability in the flow field, while in a homogeneous medium the plumes have much more uniform 10 shapes and tend to travel in a direction parallel to the average gradient. The maximum difference in detection probability over the range of $\sigma_{Y}^{2}$ considered is about $20 \%$. Figure 13 shows that $E\left(A_{d}\right)$ tends to increase as $\sigma_{Y}^{2}$ increases. The difference between the homogenous and the heterogeneous case is more pronounceable when the monitoring systems are located further away from the contaminant source, because when 15 the plumes are detected close to the source the plumes do not encounter much of the heterogeneous structure of the hydraulic conductivity as they have less chance to move a distance larger than a few correlation lengths. The results are representative for other monitoring systems evaluated in this study. After all, one may simply foresee that the more heterogeneous the medium is the higher the expected total cost of the given monitoring system will be.

\subsubsection{Sensitivity to unit costs}

For the assumed unit installation and sampling cost of $\$ 20000$ per well and a unit remediation cost of $5 \$ / \mathrm{m}^{3}$, the single row monitoring system with $n w s=0.08$ gives the minimum expected total cost, and optimal location for such a system occurs at $n d f s_{\text {opt }}=0.1$ 25 (see Figs. 8 and 9). Table 2 presents the sensitivity of the optimal well spacing and optimal location with respect to changes in the assumed unit installation and sampling cost plus unit remediation cost. The bold phase figures in the table indicate the optimal

MONIDAM for optimal groundwater monitoring system design

N. B. Yenigül et al.

\section{Title Page}

Abstract

Conclusions

Tables

14

$\triangleleft$

Back

Introduction

References

Figures

\section{Full Screen / Esc}

Print Version

Interactive Discussion 
well spacing and optimal location for the initial assumption of unit cost values.

When unit installation and sampling cost is quite high (i.e. $50000 \$ /$ well) for a unit remediation cost of $5 \$ / \mathrm{m}^{3}$ the optimal well spacing shifts to 0.12 . Fewer monitoring HESSD wells should be used to limit the expected total cost and the optimal location of the 5 monitoring system is further from the source, which means that the objective of minimizing the contaminated area can be rather loose (moving to the right of the bold phase figures). On the other hand for lower values of unit installation and sampling cost than assumed neither the optimal nws nor the $n d f s_{\text {opt }}$ do change. However, for very cheap remediation cost (e.g., $1 \$ / \mathrm{m}^{3}$ ) the optimal nws increases as the unit installation and 10 sampling cost increases up to $30000 \$ /$ well and remains the same for $40000 \$ /$ well and $50000 \$ /$ well. Likewise the monitoring wells can be located further away from the contaminant source.

If contamination can be cleaned up easier than assumed in other words if the unit remediation cost is less than the assumed value (i.e., $1 \$ / \mathrm{m}^{3}$ and $2 \$ / \mathrm{m}^{3}$ ) the nws 15 shifts to 0.12 and 0.16 , respectively, while the $n d f s_{\text {opt }}$ values correspond to 0.4 and 0.6. The increase in nws can be explained as follows. Cheap remediation allows larger plumes, which allows later detection, which leads to less wells. At the same time if the remediation of the contaminated area is much difficult than assumed due to the nature and concentration of the contaminants (moving down from the bold face figures in the 20 table) the optimal nws remains 0.08 and $n d f s_{\text {opt }}$ is kept at 0.1 . This means that limiting the extent of contamination to control the costs associated with remediation is still very important.

\subsubsection{Sensitivity to sampling frequency}

Current monitoring program suggested by regulatory agencies (i.e. USEPA, 1986 and 25 ECC, 1999) requires the monitoring of groundwater quarterly, biannually or annually depending on the type of waste, size and design of landfill and aquifer material for 30 years of post closure monitoring duration. In most cases a quarterly monitoring is un-

$3,27-68,2006$

MONIDAM for optimal groundwater monitoring system design

N. B. Yenigül et al.

\section{Title Page}

Abstract

Conclusions

Tables

14

$\triangleleft$

Back

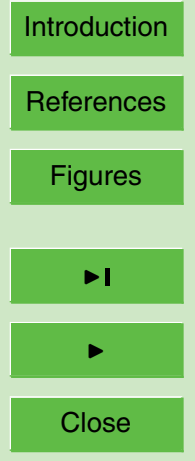

Full Screen / Esc

Print Version

Interactive Discussion 
dertaken; annual monitoring is undertaken mostly for small landfills located in remote places far away from any groundwater use. As mentioned above in this study the most common sampling frequency, namely a quarterly monitoring is considered. However, to determine the influence of sampling frequencies numerical experiments were also 5 carried out for biannually, annually, monthly and three times a year sampling. Since the leak is assumed to be continuous, sampling frequency will not affect the detection probability of a monitoring system. Because a contaminant plume will sooner or later be detected as long as the single row monitoring system is located such that it coincides with the travel path of the contaminant plume. However one may expect that 10 the main concern, with regard to sampling frequency, is early detection, in other words the extent of the contaminated area. The later the contaminant plume is detected by a given monitoring system the larger the expected contaminated area required to be remediated. The results of the analysis confirmed these arguments. The $P_{d}$ of all monitoring systems remain the same regardless of sampling frequency, while the $E\left(A_{d}\right)$ 15 increases as the sampling frequency decreases (see Fig. 14). Since the increase is not so prominent in the current example, the expected total costs will be close to each other for all sampling frequencies considered here. However, the difference in the expected total cost of monitoring systems with different sampling frequencies will be more significant when the remediation cost is much cheaper compared to monitoring costs 20 (similar to the effect presented in Table 2).

\section{Conclusions}

A multi-objective decision analysis model, MONIDAM is used to determine the optimal groundwater monitoring system, which maximizes the detection probability while minimizing the contaminated area and, the total cost of the monitoring system under conditions of uncertainties due to subsurface heterogeneity and leak locations. The results of the extensive numerical experiments show that the reliability of monitoring systems increases with distance from the contaminant source. Since plumes begin with a small

HESSD

$3,27-68,2006$

\section{MONIDAM for optimal groundwater monitoring system design}

N. B. Yenigül et al.

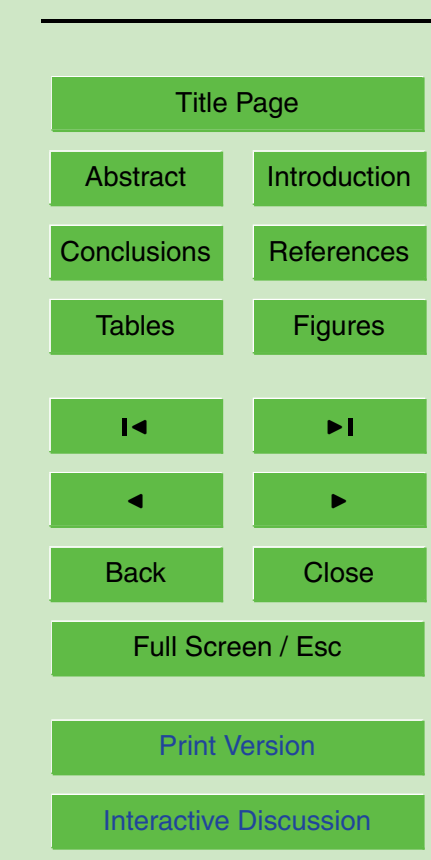

EGU 
size and spread out as they migrate away from the source, systems composed of few wells are more likely to detect the contaminant plumes when they are placed away from the contaminant source. For a given distance away from the contaminant source the probability of detection increases as the number of the monitoring wells increase 5 but once $100 \%$ of reliability is achieved by a given monitoring system additional wells would not be cost effective for improving the system reliability. The widely used 3 well monitoring system (minimum regulatory requirement) does not reach $100 \%$ reliability for any of the cases investigated in the presented study.

The contaminated area given detection increases as the distance from the source 10 increases. However the number of the wells used in a monitoring system has no influence on the size of the contaminated area, while the location of the monitoring system is crucial for minimizing the contaminated area. The nearer the monitoring systems to the contaminant source, the smaller the contaminated area will be.

The analysis furthermore demonstrated that the detection probability and the con15 taminated area increase as the dispersivity of the medium increases since it is the parameter controlling the spreading of the plume. It could give preference to those systems located further away from the contaminant source, as the detection probability is higher at further distances than in a medium with low dispersivity. Also subsurface heterogeneity is an important parameter, that has influence on detection probability and on the extent of the contaminated area. The detection probability decreases while the contaminated area increases with increasing heterogeneity. This is due to the fact that the contaminant plumes are more likely to become irregularly shaped in heterogeneous media, and they may go undetected easier due to variability in the flow field, while in homogeneous medium the plumes have much more uniform shapes and tend to travel in a direction parallel to average gradient.

The results also showed that the optimal location of the monitoring systems would be very close to the contaminant source $\left(n d f s_{\text {opt }}=0.1\right)$. A large number of wells should be considered (i.e., 12 wells) for optimal monitoring systems except for the cases where the unit installation and monitoring cost are very high and/or the unit remediation cost

HESSD

$3,27-68,2006$

MONIDAM for optimal groundwater monitoring system design

N. B. Yenigül et al.

\section{Title Page}
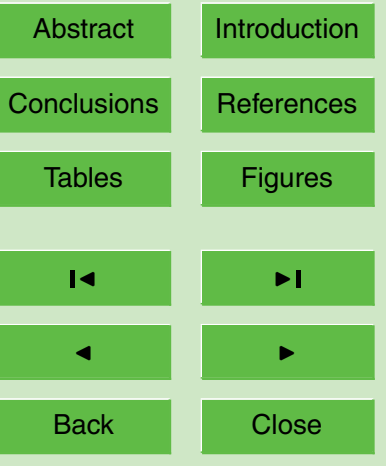

Back

Close

Full Screen / Esc

Print Version

Interactive Discussion 
is very cheap. Furthermore, the widely used 3 well monitoring system (minimum regulatory requirement) is not a good solution for any of the cases presented above. Lastly, sampling frequency has an effect on the extent of contaminated area as well. As the sampling frequency increases the contaminated area decreases. However, the reflec5 tion of this effect on the expected total cost is prominent again if the installation and monitoring cost are very high and/or the remediation cost is very cheap.

Acknowledgements. The financial support DIOC Water (Delft Interfacultair Onderzoeks Centrum voor de duurzaam gebouwde omgeving), of the Delft University of Technology and International Consulting and Engineering Company Tauw for this research is gratefully acknowledged.

\section{References}

Ababou, R., McLaughlin, D., Gelhar, L. W., and Tompson, A. F. B.: Numerical simulation of three-dimensional saturated flow in randomly heterogeneous porous media, Transport in Porous Media, 4, 549-565, 1989.

Bear, J.: Dynamics of Fluid in Porous Media, American Elsevier, New York, 1972.

Bellin, A., Saladin, P., and Rinaldo, A.: Simulation of dispersion in heterogeneous porous formations: statistics, first-order theories, convergence of computations, Water Resour. Res., 28, 2211-2227, 1992.

Chen, P. H. and Wang, C. Y.: Investigation into municipal waste leachate in the unsaturated zone of red soil, Environ. Int., 23, 237-245, 1997.

Elfeki, A. M. M.: Stochastic Characterization of Geological Heterogeneity and Its Impact on Groundwater Contaminant Transport, Ph.D. thesis, Delft University of Technology, Delft, The Netherlands, 1996.

Freeze, R. A., Massmann, J., Smith, L., Sperling, A., and James, B.: Hydrogeological decision analysis: 1. A Framework, Groundwater, 28, 738-766, 1990.

25 Freeze, R. A., James, B., Massmann, L., Sperling, A., and Smith, J.: Hydrogeological decision analysis: 4. The concept of data worth and its use in the development of site investigation strategies, Groundwater, 30, 574-588, 1992.

Gelhar, L. W.: Stochastic Subsurface Hydrology from Theory to Applications, Water Resour. Res., 22, 135-145, 1986.

\section{HESSD}

3, 27-68, 2006

\section{MONIDAM for optimal groundwater monitoring system design}

N. B. Yenigül et al.

\section{Title Page}

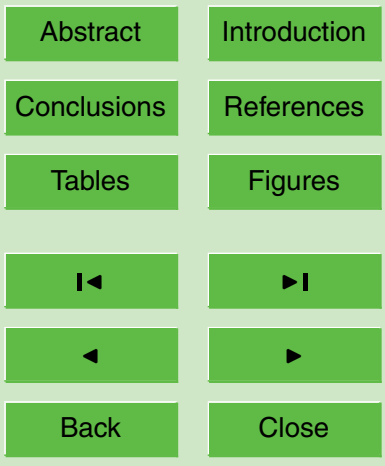

Full Screen / Esc

Print Version

Interactive Discussion 
Gorelick, S. M., Freeze, R. A., Donohue, D., and Keely, J. F.: Groundwater contamination optimal capture and containment, Lewis Publishers, United States of America, 371, 1993.

Hudak, P. F. and Loaiciga, H. A.: A location modeling approach for groundwater monitoring network augmentation, Water Resour. Res., 28, 643-649, 1993.

5 Hudak, P. F.: Effective Contaminant detection networks in uncertain groundwater flow fields, Waste Management, 21, 309-312, 2001.

Hudak, P. F.: Efficiency comparison of graphical approaches for designing contaminant detection networks in groundwater, Water Resour. Res., 38, 181-185, 2002.

James, B. R. and Gorelick, S. M.: When enough is enough: The worth of monitoring data in aquifer remediation design, Water Resour. Res., 30, 3499-3513, 1994.

Jardine, K. Smith, L., and Clemo, T.: Monitoring Networks in fractured rocks: A decision analysis approach, Groundwater, 34, 504-518, 1996.

Kinzelbach, W.: Groundwater Modeling, Development in Water Science, 25, 333, 1986.

Kjeldsen, P., Bjerg, P. L., Winther, P., Rugge, K., Pedersen, K. J., Skov, B., Foverskov, A., 15 and Christensen, T. H.: Assessment of spatial variability in leachate migration from an old landfill site, Proceedings of the Prague Conference on Groundwater Quality: Remediation and Protection, 365-373, 1995.

Koliopoulus, T. C., Kollias, V. P., and Kollias, P. S.: Modelling the risk assessment of groundwater pollution by leachates and landfill gase, Progress in Water Resources, 9, 159-169, 2003.

20 Mahar, P. S. and Datta, B.: Optimal monitoring network and groundwater pollution source identification, J. Water Resour. Planning and Management, ASCE, 23, 199-207, 1997.

Massmann, J. and Freeze, R. A.: Groundwater contamination from waste management sites: The interaction between risk-based engineering design and regulatory policy, 1 , Methodology, Water Resour. Res., 23, 351-367, 1987a.

Massmann, J. and Freeze, R. A.: Groundwater contamination from waste management sites: The interaction between risk-based engineering design and regulatory policy, 2, Results, Water Resour. Res., 23, 368-380, 1987b.

Massmann, J., Freeze R. A., Smith, L., Sperling, T., and James, B.: Hydrogeological Decision Analysis: 2. Applications to Groundwater contamination, Groundwater, 29, 536-548, 1991.

30 Meyer, P. D, Valocchi, A. J., and Eheart, J. W.: Monitoring Network Design To Provide Initial Detection of Groundwater Contamination, Water Resour. Res., 30, 2647-2659, 1994.

Montas, H. J., Mohtar, R. H., Hassan, A. E., and AlKhal, F.: Heuristic space-time design of monitoring wells for contaminant plume characterization in stochastic flow fields, J. Contam-

MONIDAM for optimal groundwater monitoring system design

N. B. Yenigül et al.

Title Page

Abstract Introduction

Conclusions References

Tables Figures

14

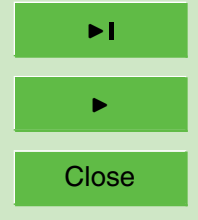

Back

Close

Full Screen / Esc

Print Version

Interactive Discussion 
inant Hydrology, 43, 271-301, 2000.

Riediker, S., Suter, J. F. M., and Giger, W.: Benzene and Naphthalenesulfonates in leachates and plumes of landfills, Water Resources, 34, 2069-2079, 2000.

Rouhani, S. and Hall T. J.: Geostatistical Schemes for Groundwater Sampling, J. Hydrol., 81, 85-102, 1988.

Storck, P., Eheart, J. W., and Valocchi, A. J.: A method for optimal location of monitoring wells for detection of groundwater contamination in three-dimensional heterogeneous aquifers, Water Resour. Res., 33, 2081-2088, 1997.

U.S. Environmental Protection Agency (USEPA): RCRA Groundwater Monitoring Technical Enforcement Guidance Document, 1986.

Yenigül, N. B., Elfeki, A. M. M., Gehrels, J. C., van den Akker, C., Hensbergen, A. T., and Dekking, F. M.: Reliability Assessment of Groundwater Monitoring Networks At Landfill Sites, J. Hydrol., 308, 1-17, 2005.

Yousef, A. R.: Study of colloidal content and associated heavy metals in landfill leachate: A 15 case study of El-Akader landfill site: Jordan, Int. J. Environ. Pollut., 23, 205-214, 2005.

\section{HESSD}

$3,27-68,2006$

\section{MONIDAM for optimal groundwater monitoring system design}

N. B. Yenigül et al.

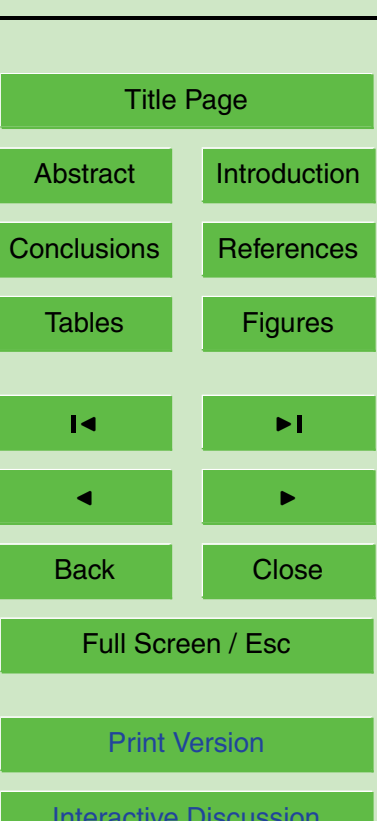

Interactive Discussion 
Table 1. Spacing, $\Delta s$, normalized well spacing, nws for different number of monitoring wells in monitoring systems with different $\mathrm{x}$-coordinates, distance from the contaminant source, $d$, and normalized distance from the source, $n d f s(L=100 \mathrm{~m})$.

\begin{tabular}{ccc}
\hline $\begin{array}{c}\text { Number of } \\
\text { the wells }\end{array}$ & $\begin{array}{c}\text { Spacing, } \\
\Delta s(\mathrm{~m})\end{array}$ & $n w s=\Delta \mathrm{s} / \mathrm{L}$ \\
\hline 3 & 33.33 & 0.33 \\
4 & 25 & 0.25 \\
5 & 20 & 0.2 \\
6 & 16.66 & 0.16 \\
8 & 12.5 & 0.12 \\
10 & 10 & 0.1 \\
12 & 8.33 & 0.08 \\
16 & 6.25 & 0.06 \\
20 & 5 & 0.05 \\
\hline
\end{tabular}

\begin{tabular}{ccc}
\hline $\begin{array}{c}\text { X-coordinate } \\
\text { of the system }\end{array}$ & $\begin{array}{c}\text { Distance from the source, } \\
d(\mathrm{~m})\end{array}$ & $\mathrm{ndfs}=d / \mathrm{L}$ \\
\hline 160 & 10 & 0.1 \\
170 & 20 & 0.2 \\
180 & 30 & 0.3 \\
190 & 40 & 0.4 \\
- & - & - \\
- & - & - \\
- & - & - \\
- & - & - \\
340 & 190 & 1.9 \\
\hline
\end{tabular}

\section{HESSD}

$3,27-68,2006$

MONIDAM for optimal groundwater monitoring system design

N. B. Yenigül et al.

Title Page

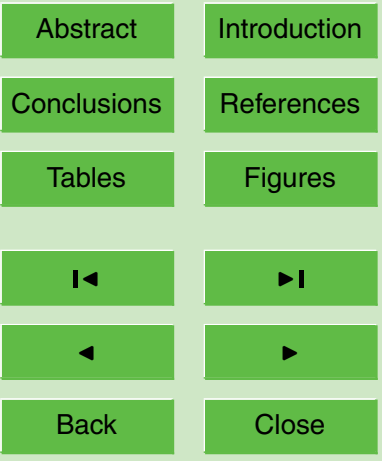

Full Screen / Esc

Print Version

Interactive Discussion 


\section{HESSD}

3, 27-68, 2006

Table 2. Optimal well spacing and optimal location as function of unit remediation cost and unit installation and sampling cost.

\section{MONIDAM for optimal groundwater monitoring system design}

N. B. Yenigül et al.

\begin{tabular}{|c|c|c|c|c|c|c|c|c|c|c|c|c|}
\hline \multirow{3}{*}{$\begin{array}{l}\text { Unit remediation } \\
\qquad \operatorname{cost}(\$ / \mathrm{m} 3)\end{array}$} & \multicolumn{12}{|c|}{ Unit installation and sampling cost (\$/well) } \\
\hline & \multicolumn{2}{|c|}{5000} & \multicolumn{2}{|c|}{10000} & \multicolumn{2}{|c|}{20000} & \multicolumn{2}{|c|}{30000} & \multicolumn{2}{|c|}{40000} & \multicolumn{2}{|c|}{50000} \\
\hline & nws & $n d f s_{\text {opt }}$ & nws & $n d f s_{\mathrm{opt}}$ & nws & $n d f s_{\text {opt }}$ & nws & $n^{n d f s_{\text {opt }}}$ & nws & $n d f s_{\mathrm{opt}}$ & nws & $n d f s_{\mathrm{opt}}$ \\
\hline 1 & 0.08 & 0.1 & 0.12 & 0.4 & 0.16 & 0.6 & 0.20 & 0.7 & 0.20 & 0.7 & 0.20 & 0.7 \\
\hline 2 & 0.08 & 0.1 & 0.08 & 0.1 & 0.12 & 0.4 & 0.12 & 0.4 & 0.16 & 0.6 & 0.16 & 0.6 \\
\hline 3 & 0.08 & 0.1 & 0.08 & 0.1 & 0.08 & 0.1 & 0.12 & 0.4 & 0.12 & 0.4 & 0.12 & 0.4 \\
\hline 4 & 0.08 & 0.1 & 0.08 & 0.1 & 0.08 & 0.1 & 0.08 & 0.1 & 0.12 & 0.4 & 0.12 & 0.4 \\
\hline 5 & 0.08 & 0.1 & 0.08 & 0.1 & 0.08 & 0.1 & 0.08 & 0.1 & 0.08 & 0.1 & 0.12 & 0.4 \\
\hline 6 & 0.08 & 0.1 & 0.08 & 0.1 & 0.08 & 0.1 & 0.08 & 0.1 & 0.08 & 0.1 & 0.10 & 0.3 \\
\hline 7 & 0.08 & 0.1 & 0.08 & 0.1 & 0.08 & 0.1 & 0.08 & 0.1 & 0.08 & 0.1 & 0.08 & 0.1 \\
\hline 8 & 0.08 & 0.1 & 0.08 & 0.1 & 0.08 & 0.1 & 0.08 & 0.1 & 0.08 & 0.1 & 0.08 & 0.1 \\
\hline 9 & 0.08 & 0.1 & 0.08 & 0.1 & 0.08 & 0.1 & 0.08 & 0.1 & 0.08 & 0.1 & 0.08 & 0.1 \\
\hline 10 & 0.08 & 0.1 & 0.08 & 0.1 & 0.08 & 0.1 & 0.08 & 0.1 & 0.08 & 0.1 & 0.08 & 0.1 \\
\hline
\end{tabular}




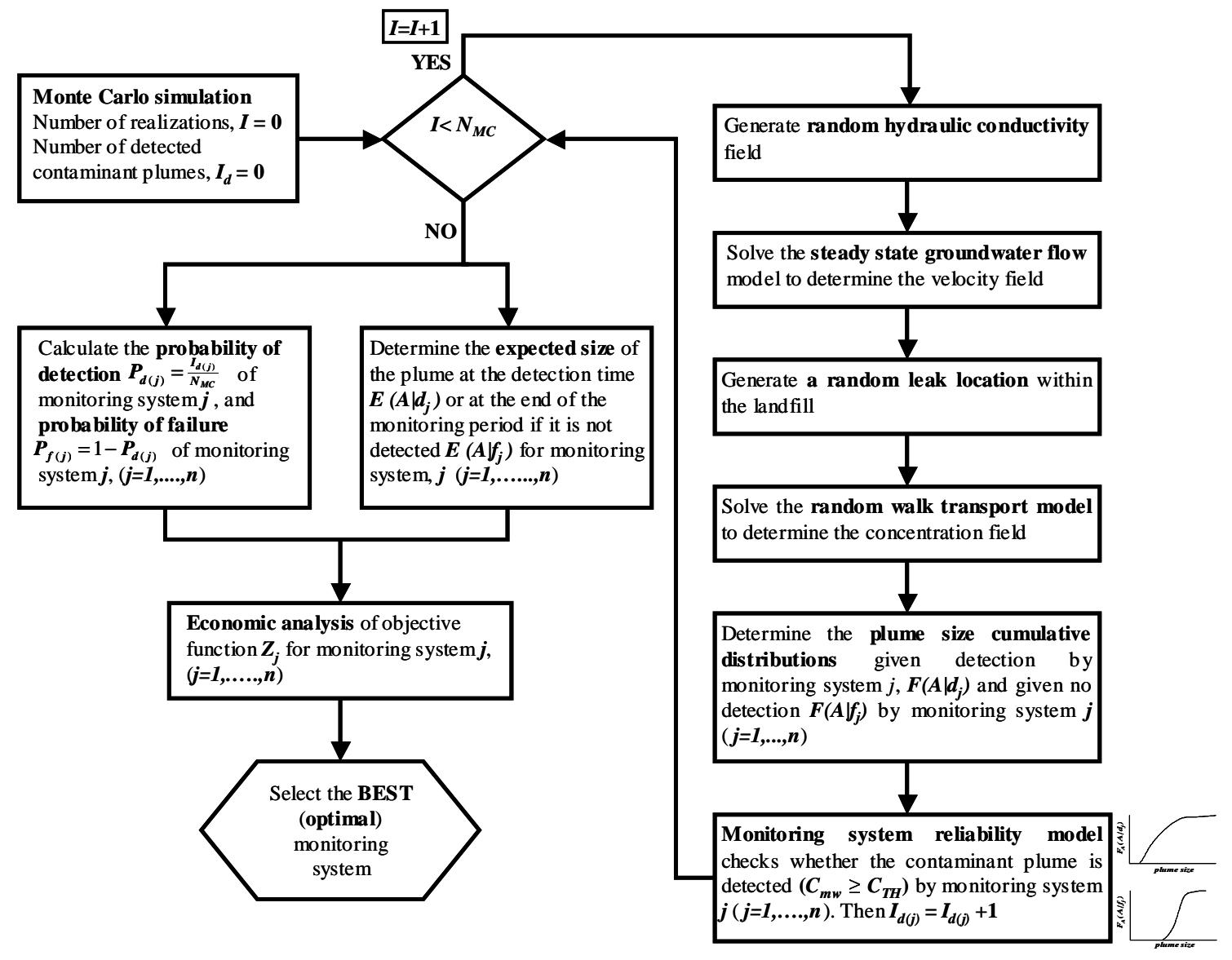

\section{HESSD}

$3,27-68,2006$

\section{MONIDAM for optimal groundwater monitoring system design}

N. B. Yenigül et al.

\section{Title Page}

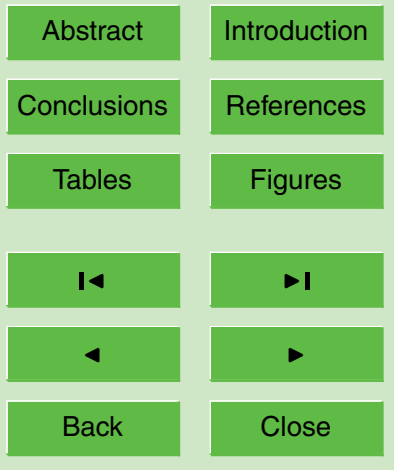

Full Screen / Esc

Print Version

Fig. 1. Flow chart illustrating the structure of the decision model MONIDAM. 


\section{HESSD}

$3,27-68,2006$

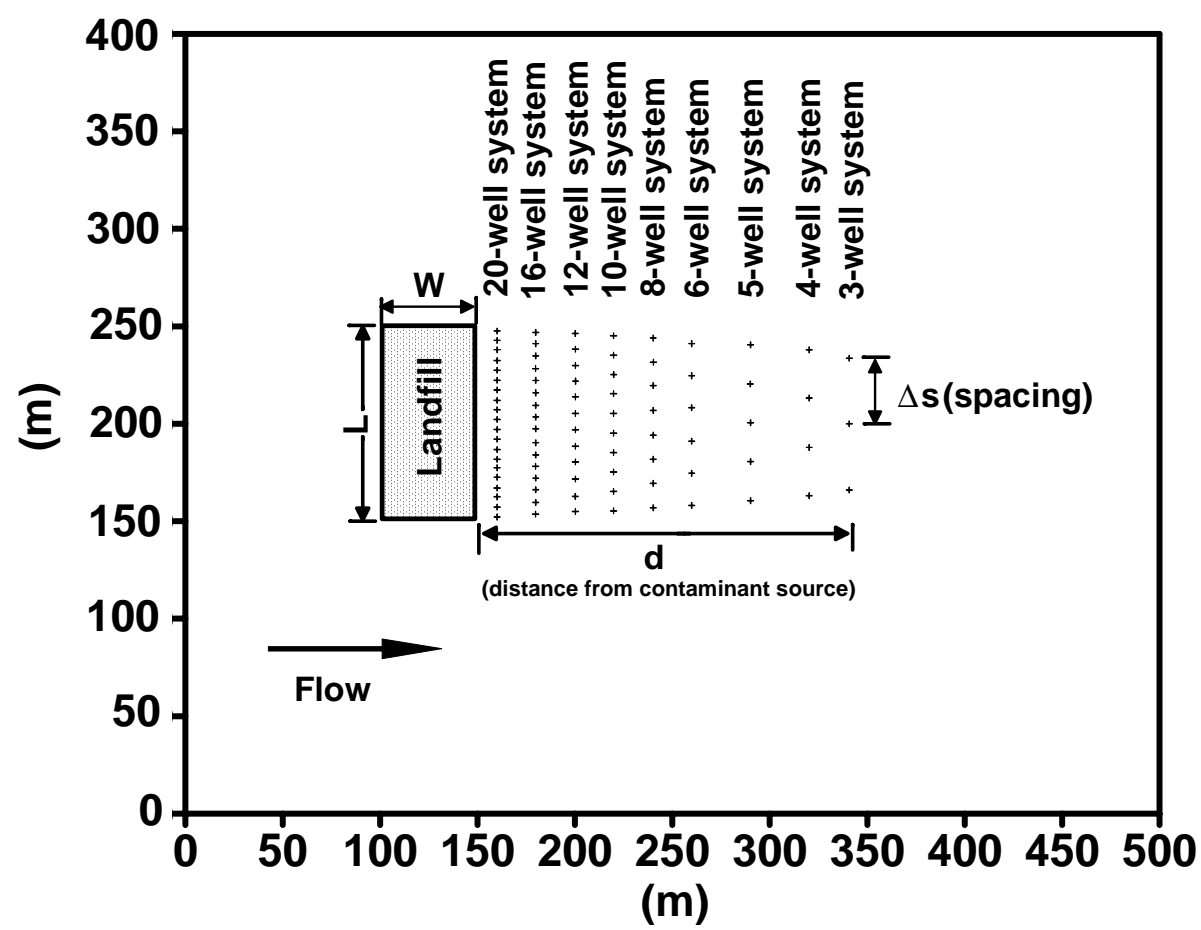

Fig. 2. Dimensions and components of example problem used in numerical experiments (Note: the spacing between the first (or last) well and the $y=150 \mathrm{~m}$ (respectively $\mathrm{y}=250 \mathrm{~m}$ ) line equals to $\Delta s / 2)$.

\section{MONIDAM for optimal groundwater monitoring system design \\ N. B. Yenigül et al.}

\section{Title Page}

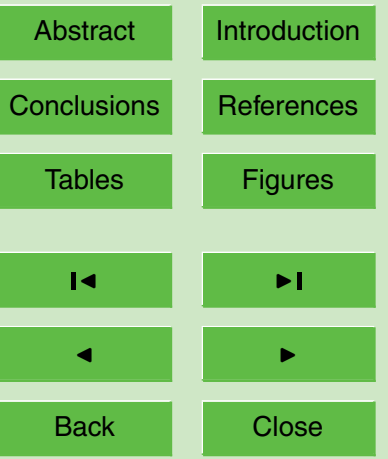

Full Screen / Esc

Print Version

Interactive Discussion 


\section{HESSD}

3, 27-68, 2006

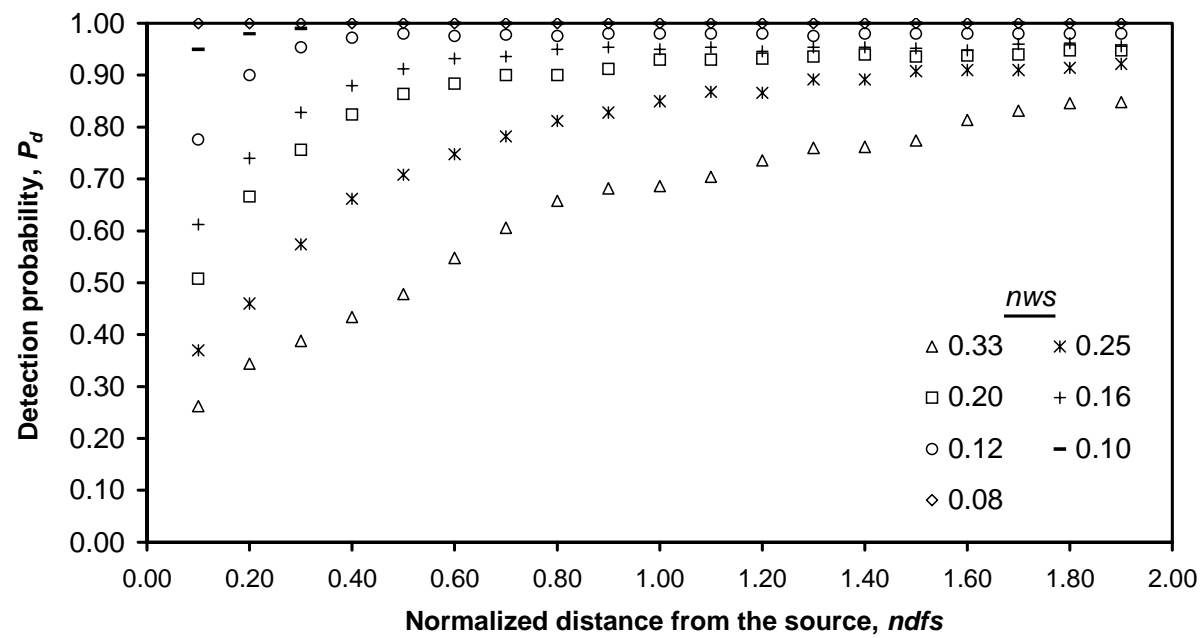

MONIDAM for optimal groundwater monitoring system design

N. B. Yenigül et al.

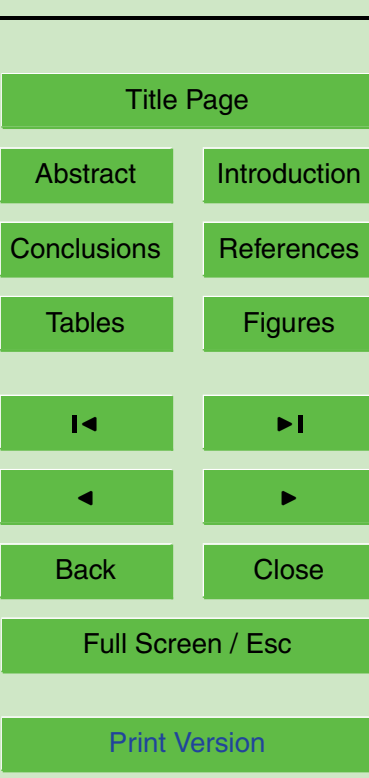

Interactive Discussion 


\section{HESSD}

$3,27-68,2006$

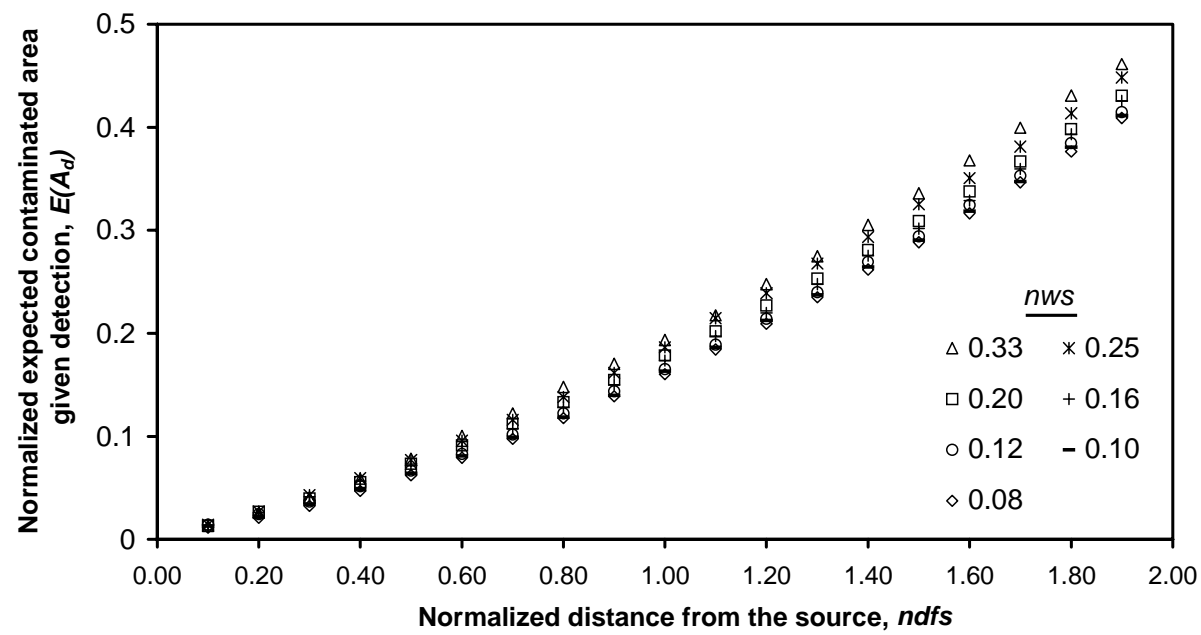

MONIDAM for optimal groundwater monitoring system design

N. B. Yenigül et al.

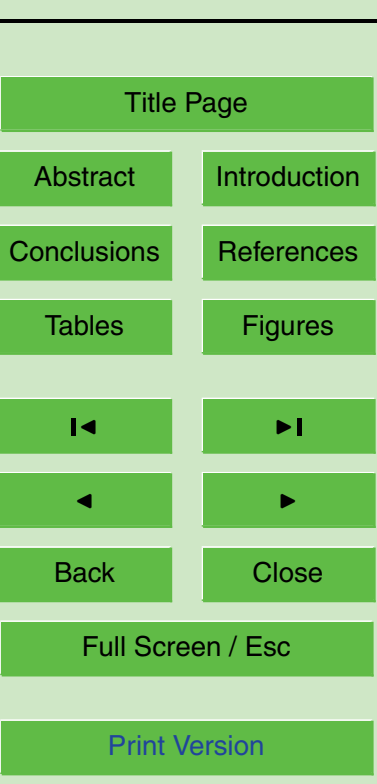

Interactive Discussion

Fig. 4. Normalized expected contaminated area given detection $E\left(A_{d}\right)$ as a function of normalized distance from the source ndfs for single row monitoring systems with different normalized well spacing nws. 


\section{HESSD}

$3,27-68,2006$
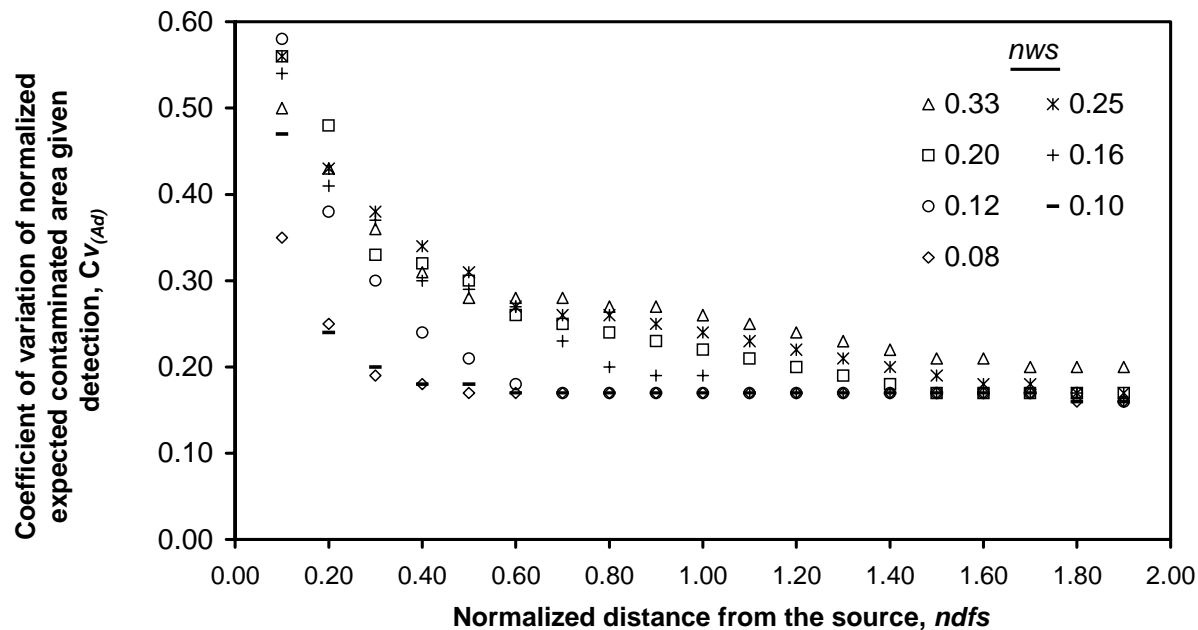

Fig. 5. Coefficient of variation of expected contaminated area given detection $C V_{A(d)}$ as a function of normalized distance from the source ndfs for single row monitoring systems with different normalized well spacing nws.

\section{MONIDAM for optimal groundwater monitoring system design}

N. B. Yenigül et al.

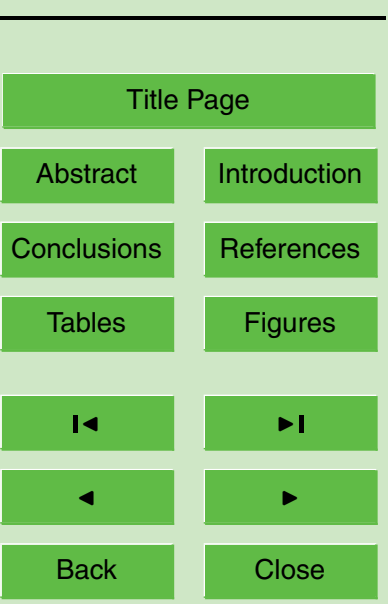

Full Screen / Esc

Print Version

Interactive Discussion 


\section{HESSD}

$3,27-68,2006$

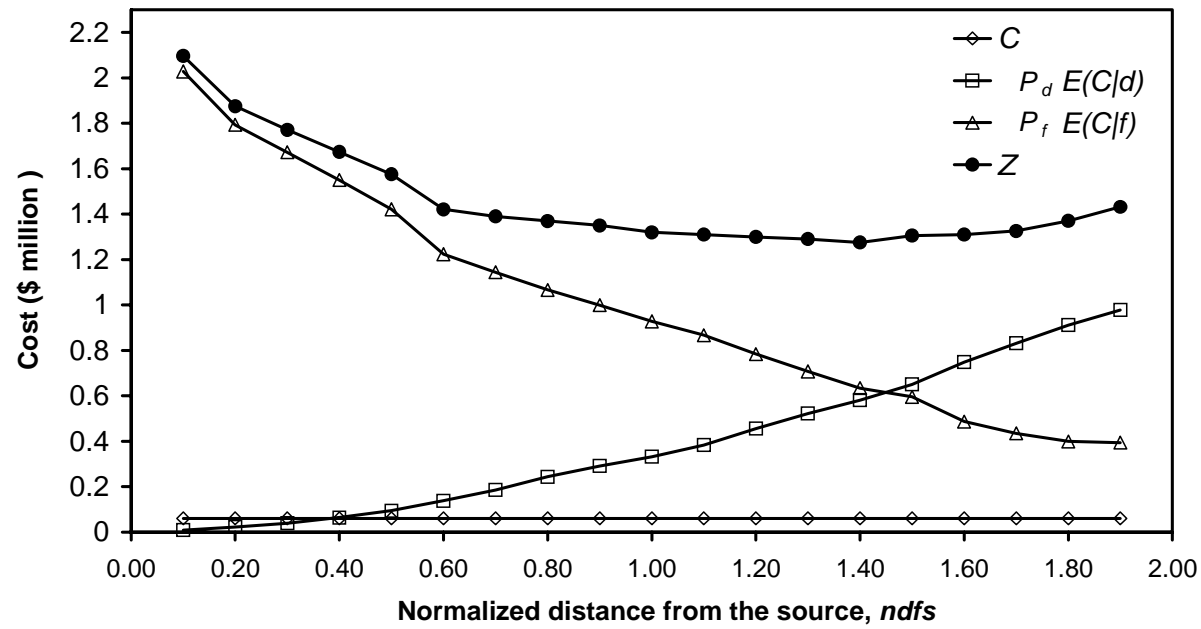

Fig. 6. Cost values as a function of normalized distance from the source ndfs for a single row monitoring system with 3 wells (nws=0.33).

\section{MONIDAM for optimal groundwater monitoring system design}

N. B. Yenigül et al.

\section{Title Page}

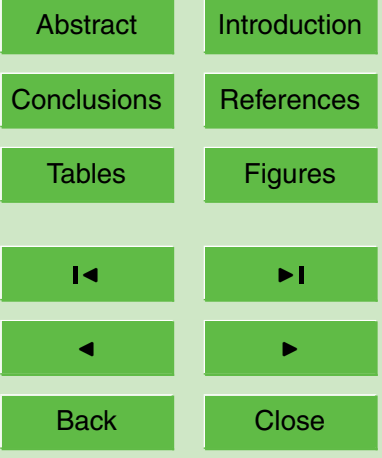

Full Screen / Esc

Print Version

Interactive Discussion 


\section{HESSD}

3, 27-68, 2006

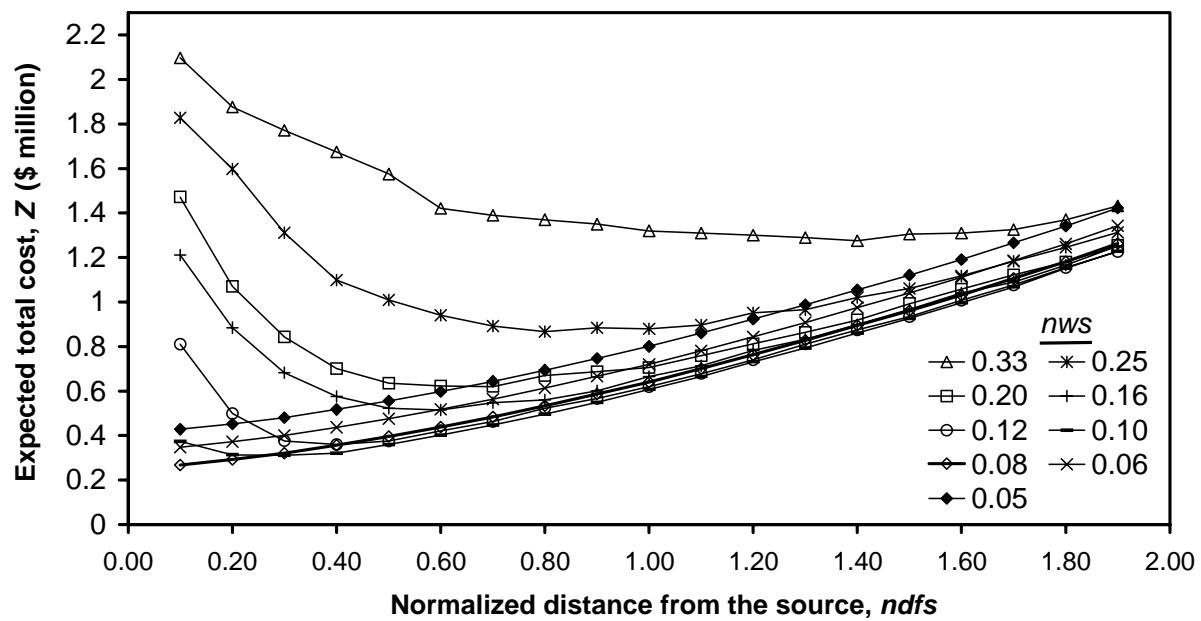

\section{MONIDAM for optimal groundwater monitoring system design}

N. B. Yenigül et al.

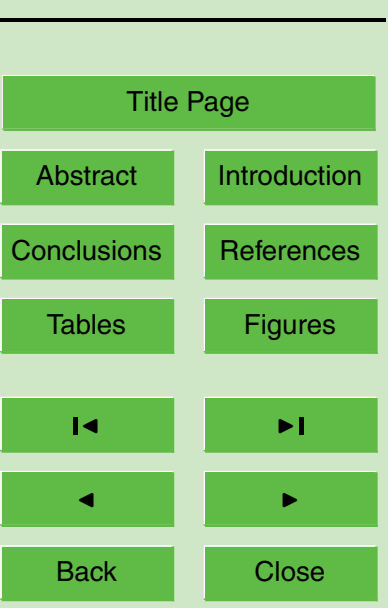

Full Screen / Esc

Print Version

Interactive Discussion 


\section{HESSD}

$3,27-68,2006$

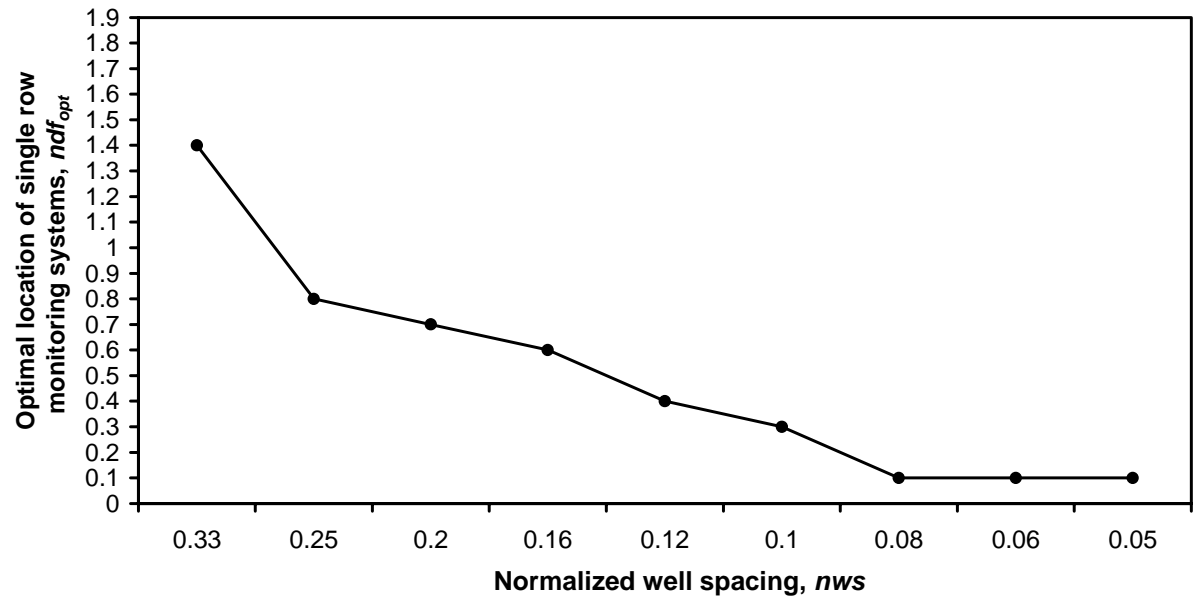

\section{MONIDAM for optimal groundwater monitoring system design}

N. B. Yenigül et al.

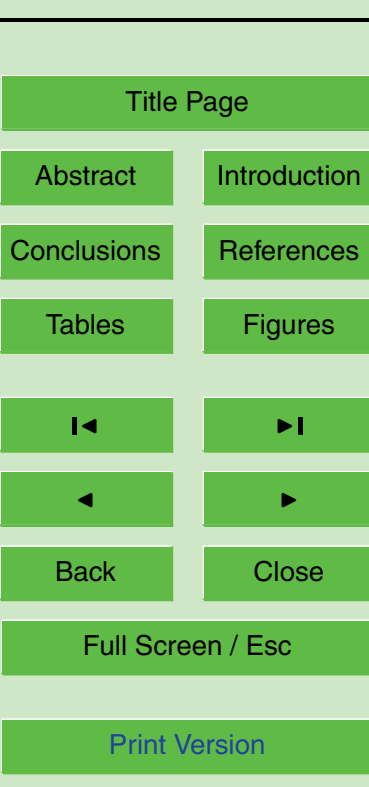

Interactive Discussion

Fig. 8. Optimal location of single row monitoring systems $n d f s_{\text {opt }}$, as a function of normalized well spacing $n w s$. 


\section{HESSD}

3, 27-68, 2006

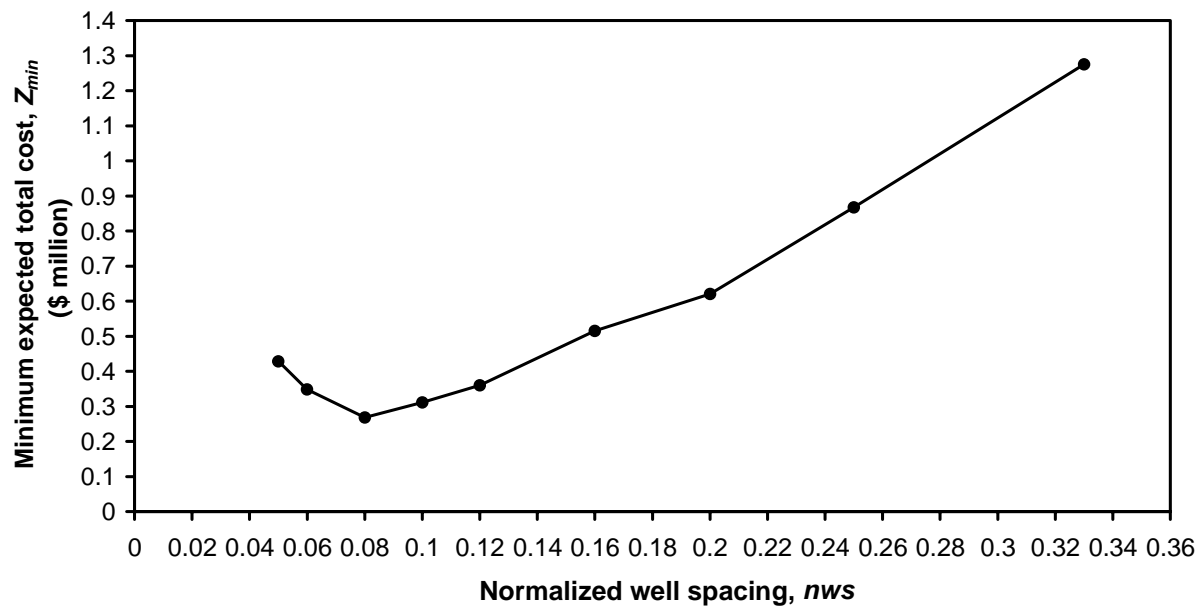

\section{MONIDAM for optimal groundwater monitoring system design}

N. B. Yenigül et al.

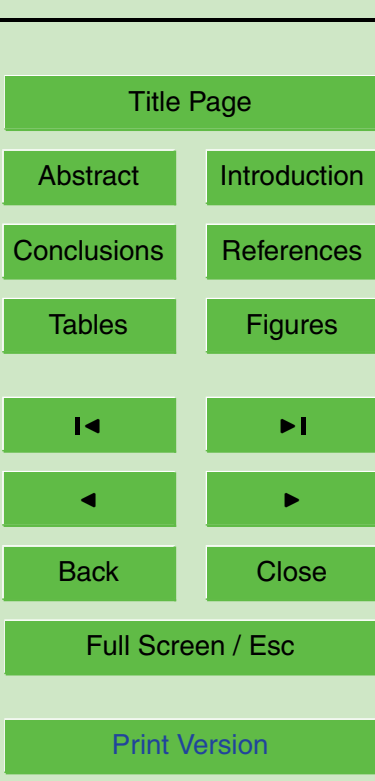

Interactive Discussion 


\section{HESSD}

$3,27-68,2006$

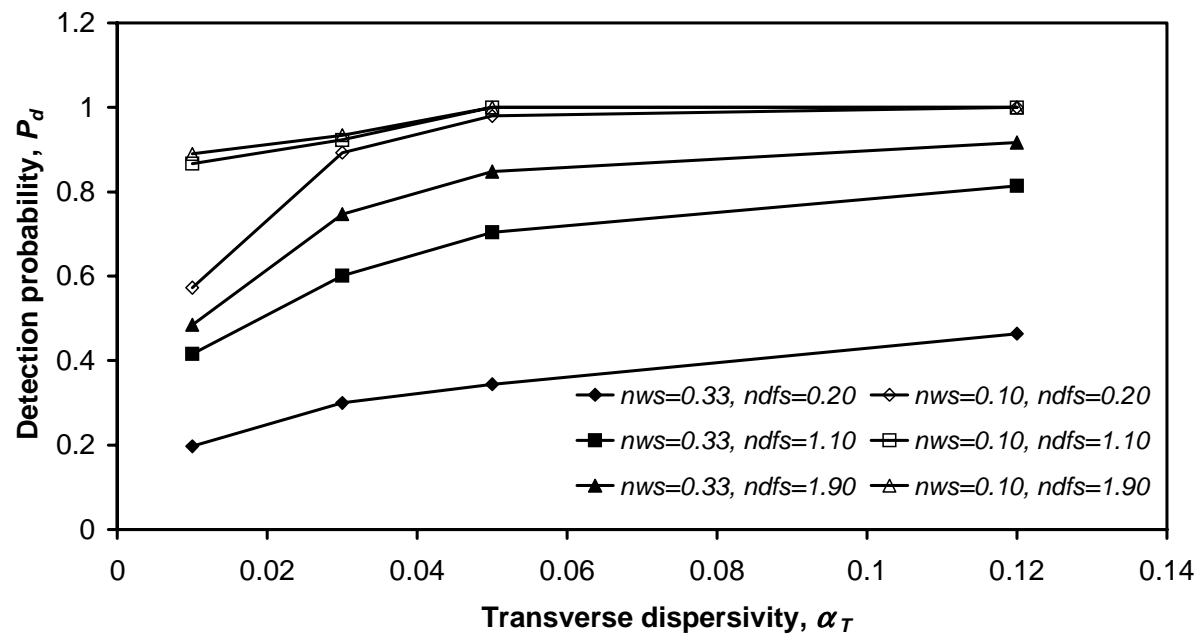

\section{MONIDAM for optimal groundwater monitoring system design}

N. B. Yenigül et al.

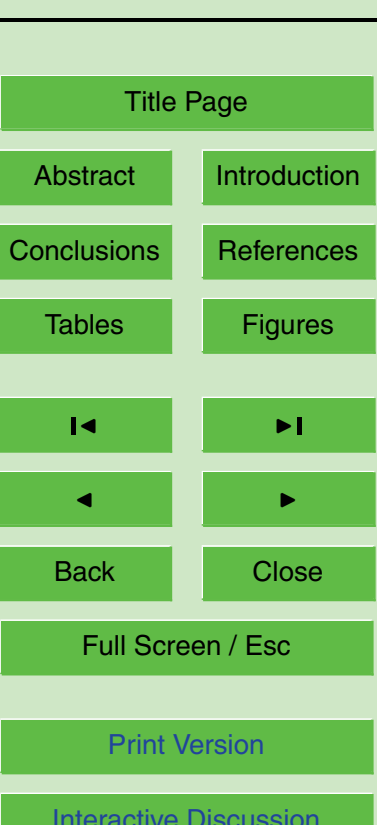

Interactive Discussion

Fig. 10. Detection probability $P_{d}$ as a function of transverse dispersivity $\alpha_{T}$, for selected single row monitoring systems. 


\section{HESSD}

3, 27-68, 2006

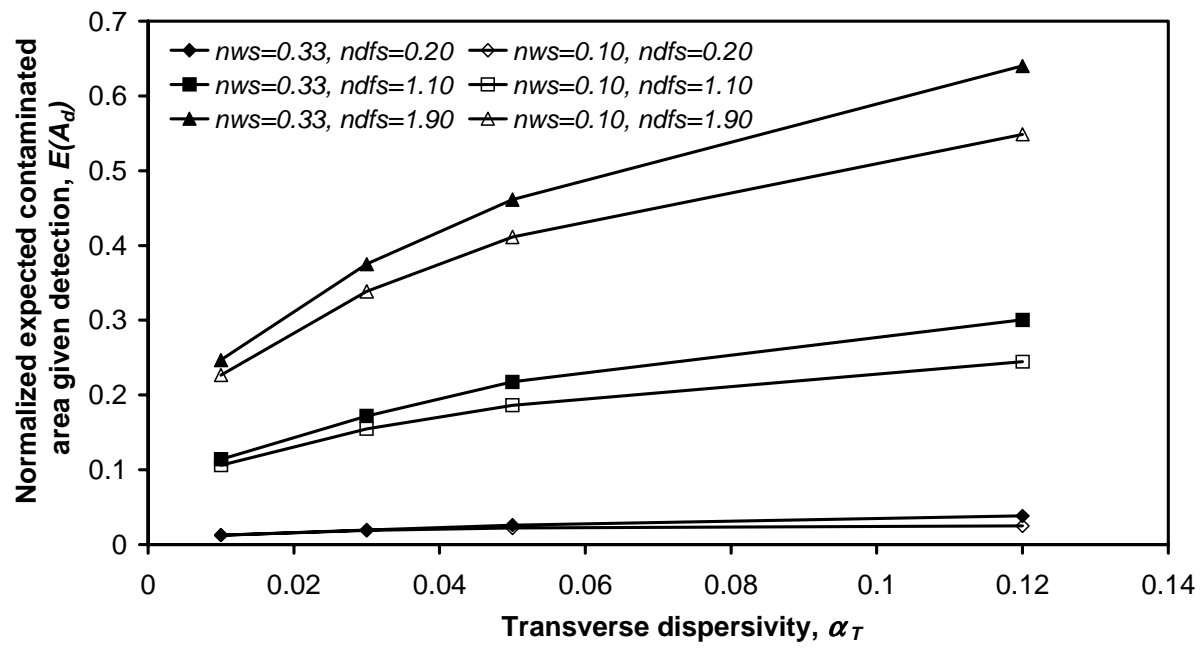

\section{MONIDAM for optimal groundwater monitoring system design}

N. B. Yenigül et al.

\section{Title Page}

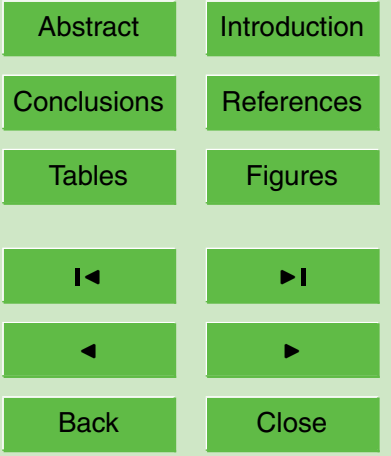
verse dispersivity $\alpha_{T}$, for selected single row monitoring systems.

\section{Full Screen / Esc}

\section{Print Version}




\section{HESSD}

3, 27-68, 2006

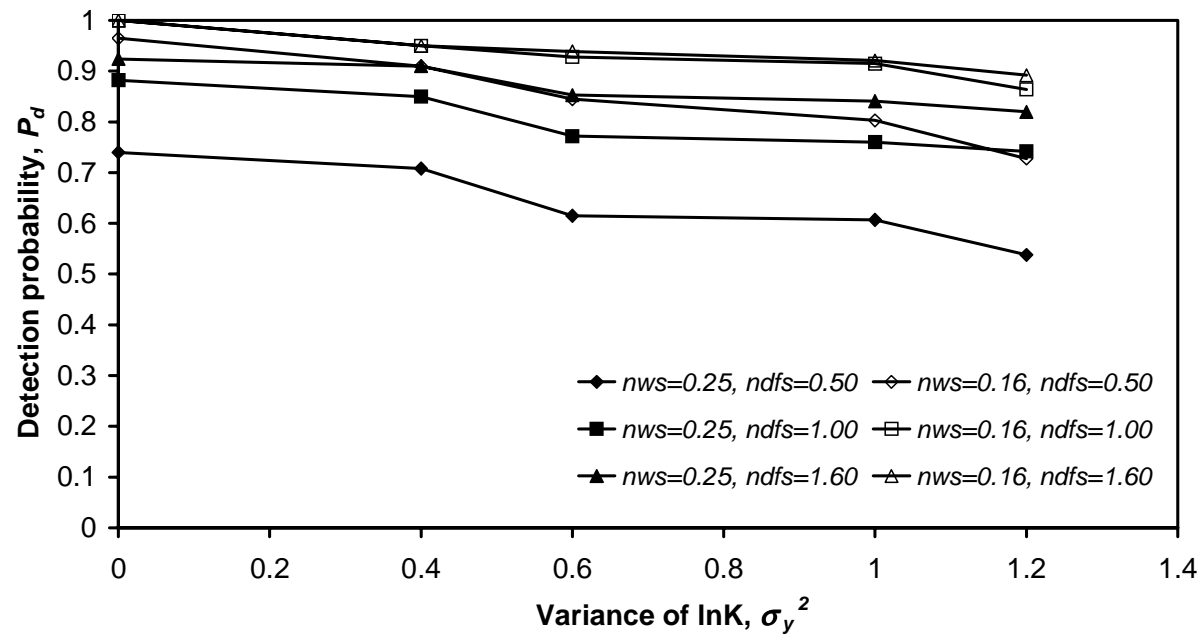

MONIDAM for optimal groundwater monitoring system design

N. B. Yenigül et al.

\section{Title Page}

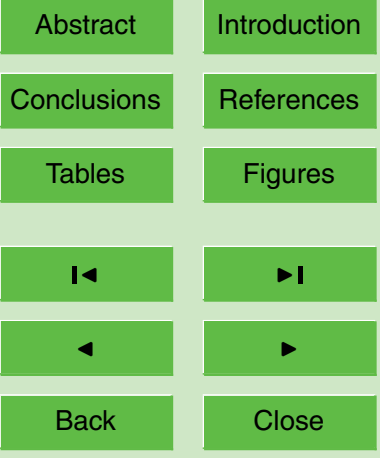

Full Screen / Esc

Print Version

Interactive Discussion 


\section{HESSD}

3, 27-68, 2006

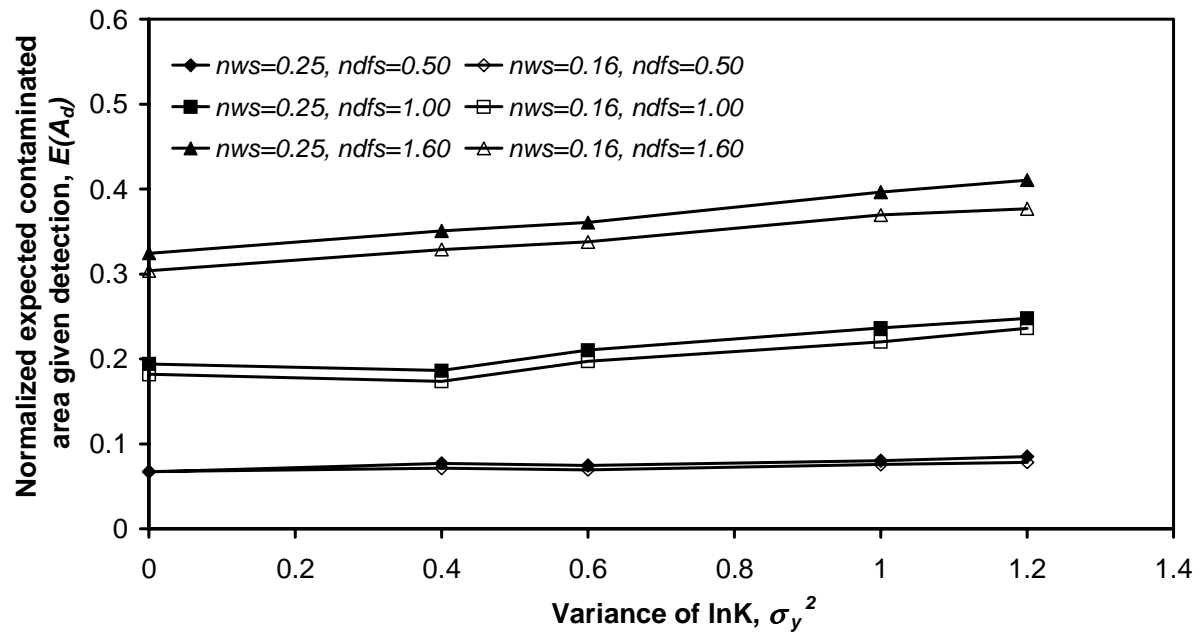

\section{MONIDAM for optimal groundwater monitoring system design}

N. B. Yenigül et al.

\section{Title Page}

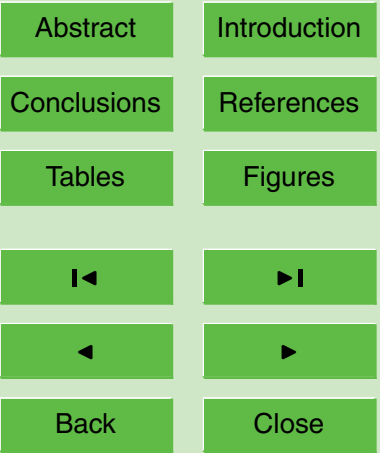

\section{Full Screen / Esc}

Print Version

Interactive Discussion 


\section{HESSD}

$3,27-68,2006$

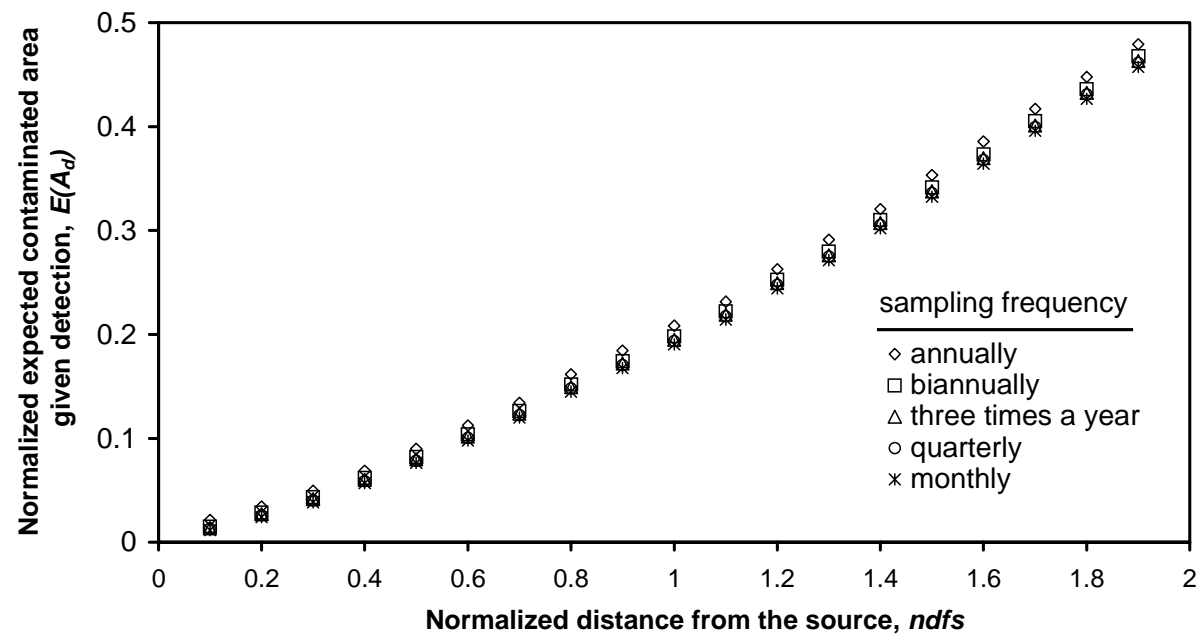

MONIDAM for optimal groundwater monitoring system design

N. B. Yenigül et al.

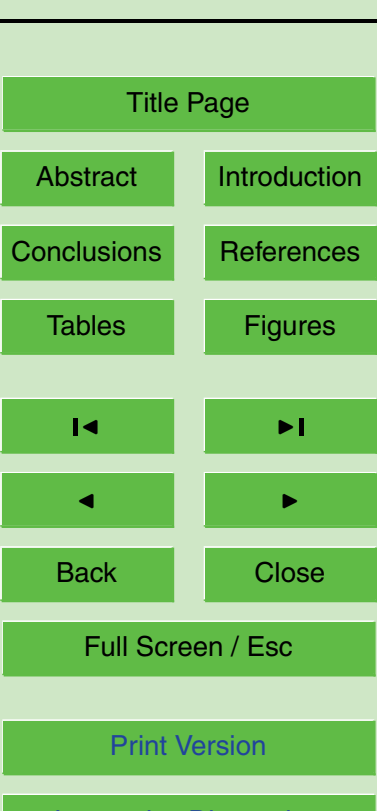

Interactive Discussion

Fig. 14. Normalized expected contaminated area given detection $E\left(A_{d}\right)$ as a function of normalized distance from the source $n d f s$ for a single row monitoring system with 3 wells (nws $=0.33$ ) for different sampling frequencies. 